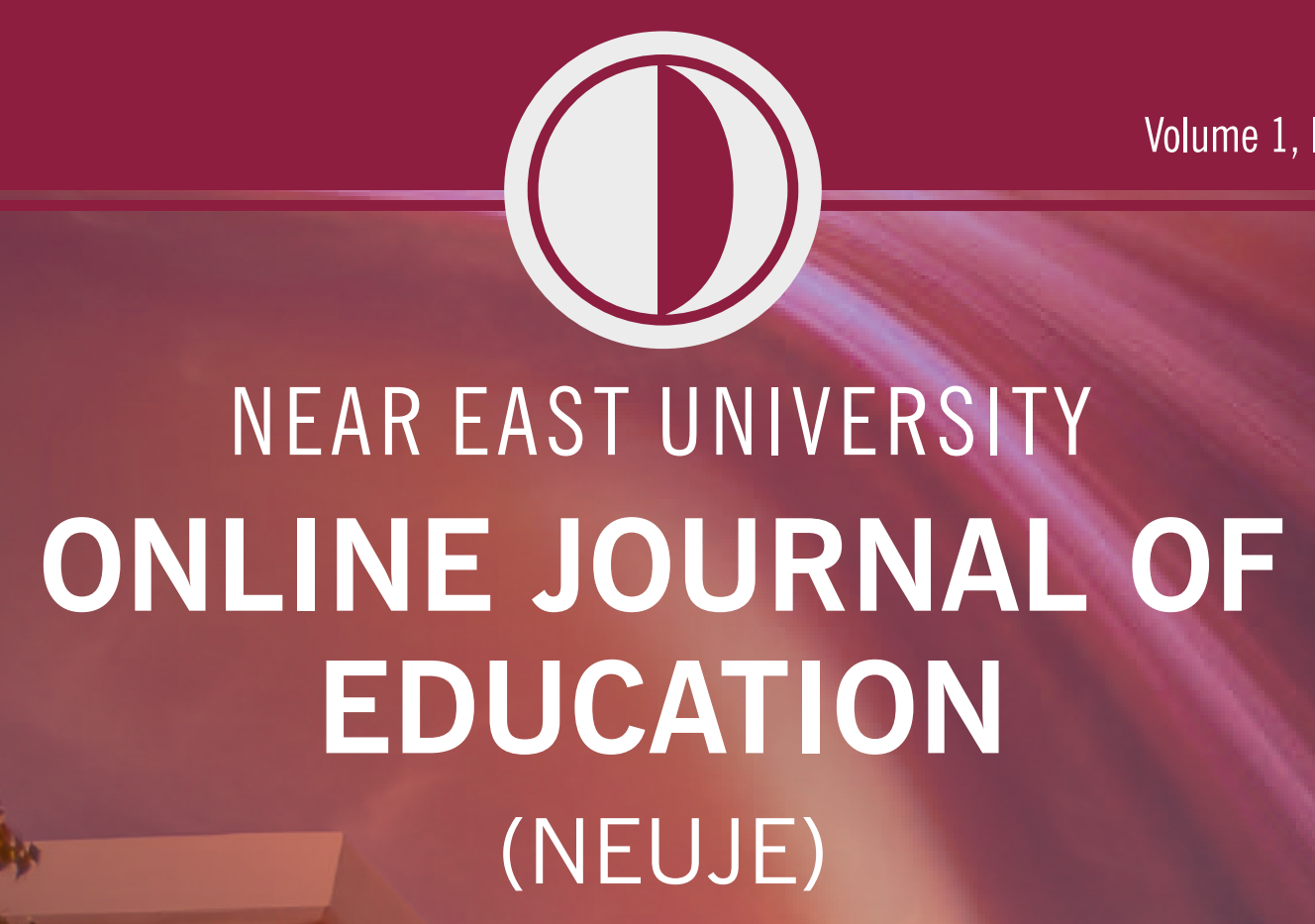

7

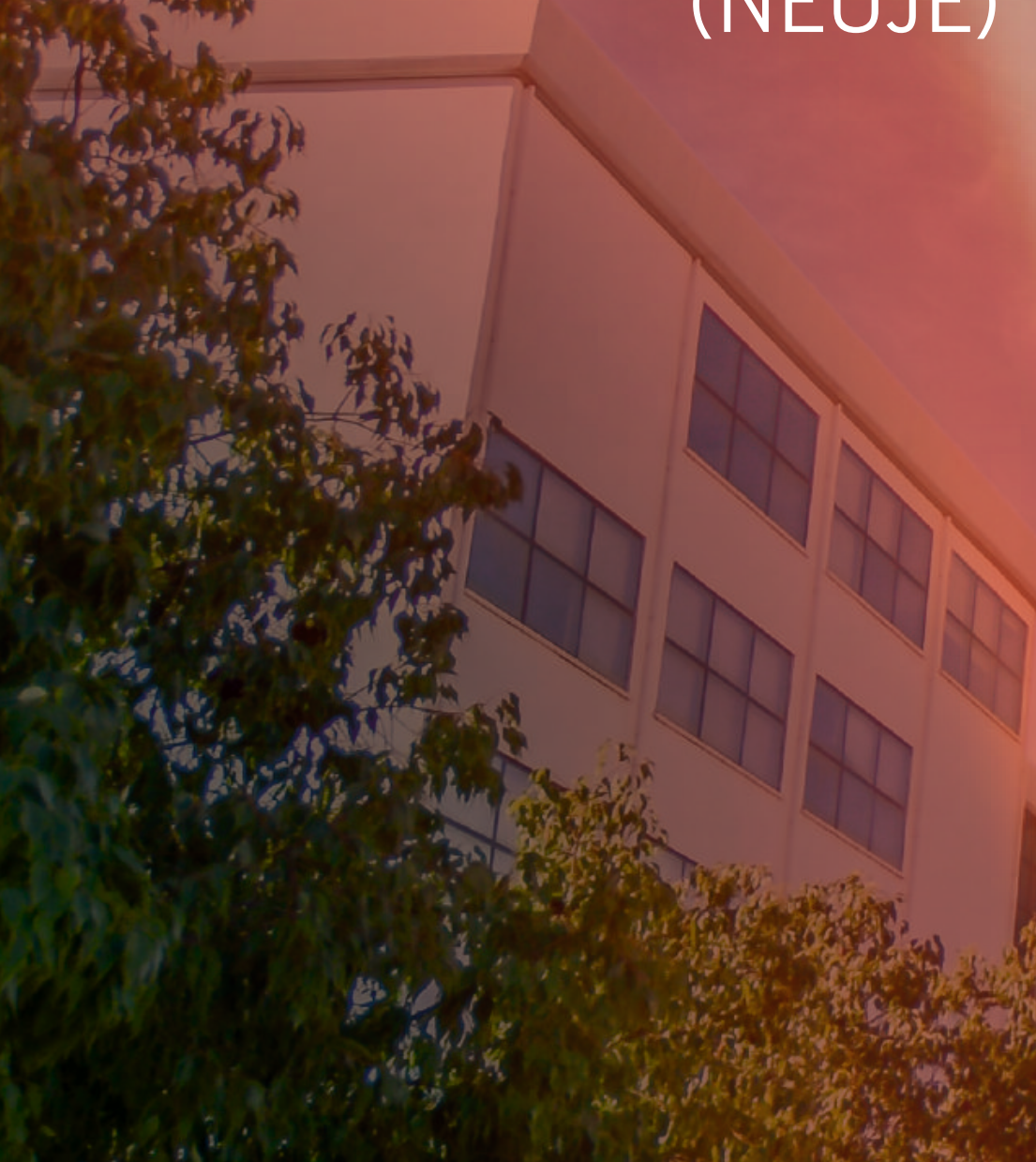




\title{
AN INVESTIGATION INTO CONTENT EVALUATION OF PROGRAMS BETWEEN 2013 - 2018
}

\author{
Felix Danjuma Tappi ${ }^{1}$, Cigdem Hursen ${ }^{2, *}$ \\ ${ }^{1}$ Division of Curriculum and Instruction, Ataturk Education Faculty, Near East University, North Cyprus, Via \\ Mersin 10, Turkey, felixtappidanjuma@ gmail.com \\ ${ }^{2}$ Division of Curriculum and Instruction, Ataturk Education Faculty, Near East University, North Cyprus, Via \\ Mersin 10, Turkey, cigdem.hursen@neu.edu.tr \\ Correspondence: cigdem.hursen@neu.edu.tr; Tel.: +90(392) 2236464
}

\begin{abstract}
This research was conducted following specific content evaluation of programs between the period of 2015 - 2018 with limitations, a content analysis related studies on evaluation of programs to specify the direction of the research using qualitative study to analyze search results for four years. The Science Direct Data Base was searched to collect the data and journals were scanned to reach 72 studies. The aim of this research is to improve evaluation program effectiveness and to encourage researchers to study in this field. This study focused on program evaluation and answers were sought for distribution of studies by year of publication, subject area, country, method, and sample. The findings revealed that studies on program evaluation were mostly carried out in 2015 and 2018. The findings revealed that qualitative research was used more than quantitative and the mixed method. The result also revealed that most of the studies analyzed were in the area of teacher education and educational research. The analysis was done by the two researchers and for any disagreement, researchers studied on the issue and reached complete agreement. The data obtained from the studies were analyzed through descriptive statistic after calculating their frequency and percentage values.
\end{abstract}

Keywords: content analysis, evaluating programs, investigating, qualitative

\section{Introduction}

In our world today, new technologies are fast emerging, new industries are also booming, new cultures are being adopted, new political powers are also surfacing, therefore the need to raise quality individuals who can respond to the expectations of this changing world at enormous speed in this era of flexibility and change, there should be effective research questions on the new trends, determination which can only be possible through functional education systems being the backbone of development and educational programs serves as the essential elements of the whole system (Cai \& Cirillo, 2014; Sahafque \& Mohammed, 2013). Educational programs are not only considered to be effective as a factor in a competitive and economic development (Clemente, Ramirez \& Dominguez, 2000) with significant role in the transfer of cultural values, and beliefs to the new generations. The quality of our teachers and students today are measured by the quality control standards being worked upon at the stage of curriculum planning. Efforts must be made in order to prepare students who can survive and further develop themselves towards responding to this challenges on the 21 st century Dolls (1992).

Educational programs include the following: targets, content, educational activities and assessment selection criteria focus on the questions regarding what; when; how students or learners will learn (Cai \& Cirillo, 2014). The emphasis on educational programs is for 
researchers to throw light by giving the explanation that is expected to meet the students learning outcomes that are functional, applicable, flexible, scientific and subject to alteration (Skinner, 2014; Erden, 1998; Vans, 1996). The art of teaching and learning is the interaction or communication that occurs between both human and material resources in a classroom setting (Brain, 2014), while Evening (2001) suggested that the art of teaching as a profession should encompass both instructions in the procedures, being a process to guiding students or learners to the information the deserved and challenging them to engage in the thinking about concepts they construct in their inner minds to be creative in return. Cai and Cirillo (2014) expressed worries and draws the attention to the fact that the biggest problem most students are facing today in the learning processes is their attitude of trying to memorize information given than careful studying to comprehend and to be able to apply the knowledge learnt into real situations. Taylor (2013) in his submission mentioned on the dynamic interaction between teachers and the educational programs and went further to emphasized that teachers' effective applications of the programs facilitates learning in no small measure.

Curriculum includes total courses that students offer and the related process and arrangement. Curriculum evaluation process, the participative decision making is key in the new nominal domain of leadership (Ratsoy \& Bing, 1999). Facing employment pressure from the growing population. Complex information can make evaluation procedure difficult. In this light, this research aimed at investigating the studies carried out in program evaluation in the scope of four years and guide the researchers in the future studies and new trends in program evaluation was considered for specification. There is the need to review the tendencies of other researchers.

\section{Aim of the Study}

This study aims to carry out a content analysis of evaluation of programs and determined the trends in this field and in line with this general aim answers to the following questions were sought in the study.

1. To which years were the studies carried out in program evaluation scanned and published?

2. What is the distribution of studies in based on subject area?

3. What is the distribution of studies based on countries?

4. What is the data collection techniques used in the studies?

5. What is the method used in used in the studies?

6. What is the Distribution of Sample used in the studies?

\section{Method}

In this section, research model, data collection tool and data analysis are explained in detail.

\subsection{Research Model}

A qualitative content analysis method was used in the search to analyze papers in this study. The data were analyzed with content analysis to reach the concepts and relations that assist to explain the 72 data collected from the Science Direct Data Base search. The basic procedure in content analysis is to gather similar data that explain certain concepts and explain them in such a way that readers will understand. Content analysis has been so effective and has been used to examine the evolution of other disciplines. 


\subsection{Sample}

The sample for this study was composed of 72 studies published in the Science Direct Journals on curriculum evaluation of programs with limitations for the selection of the studies.

\subsection{Data Collection Tool}

In this study, a program evaluation classification in line with the aim of the study was used as tool to collect the data. This form composed of six sections which include: the year of publication of studies, the subjects, the countries of research, data collection techniques, the method used, and the Sample used in the studies. Data for the study were collected from the journals scanned in the Data Base of Science Direct. Through scanning electronic data base which revealed a total of 72 Journals reached were the ones published in the year 2015, 2016, 2017, and 2018. At the same time also, the data collection process, the keywords" curriculum evaluation and teacher education" were used. The articles obtained from the journals published in data base, were analyzed through the criteria formed into sub-targets of this research.

- Publication year

- Publication by Subject area

- Countries of research

- Data collection techniques

- Data collection method

- Sample used within the scope

\subsection{Data Analysis}

The content analysis was carried out by an instructor and a Ph.D. Student. The writers worked together so that the articles were classified reliably. The data obtained from the articles were carefully analyzed in line accordance with the research questions through descriptive statistics. The articles' metadata were analyzed based on the criteria involving year of publication, subjects, sample, countries of authors, method, and type of study. The data were put into tables of frequency and percentage values.

\section{Results}

In this section, the results of the findings are presented and discussed in line with the aim and framework of the study.

\subsection{Distribution of Studies in Terms of Year}

As it can be seen Table 1, the number of articles dealing with program evaluation in Journals obtained from Science Direct Data Base revealed that most of the studies were done in 2015 with frequency of 18(25) and 2018 with frequency of 22(30.56\%). The increase of articles in 2018 shows how interested researchers are on the field with 22(30.56\%) journal publications.

Table 1. Results by Year

\begin{tabular}{lll}
\hline Year & Document & \% \\
\hline 2018 & 22 & 30.56 \\
\hline 2017 & 16 & 22.22 \\
\hline 2016 & 16 & 22.22 \\
\hline 2015 & 18 & 25 \\
\hline Grand total & 72 & 100 \\
\hline
\end{tabular}




\subsection{Distribution of Subject Area within the Scope of This Research}

Table 2. Shows the Distribution of the Subject Area within the Scope of This Research

\begin{tabular}{lll} 
Study Topics & f & \% \\
\hline Teacher Education & 23 & 31.94 \\
\hline Educational Research & 14 & 19.44 \\
\hline Social and Behavioral Sciences & 7 & 9.72 \\
\hline Curriculum Studies & 6 & 8.33 \\
\hline Psychology & 6 & 8.33 \\
\hline Technology & 4 & 5.56 \\
\hline Special Education & 4 & 5.56 \\
\hline Physical Education & 3 & 4.17 \\
\hline Guidance \& Counselling & 2 & 2.78 \\
\hline Mathematical thinking & 2 & 2.78 \\
\hline Mathematics & 1 & 1.39 \\
\hline Grand Total & 72 & 100 (rounded) \\
\hline
\end{tabular}

As it can be noted in Table 2, program evaluation studies the various Subjects, mostly in Teacher Education with frequency of 23(31.94\%) and Educational Research with frequency of $14(19.44 \%)$. The least study was in field of Mathematics with a frequency of 1(1.39\%) study.

\subsection{Distribution of the Studies Investigated in Terms of Countries}

Table 3a. Distribution of Studies by Countries

\begin{tabular}{lcc}
\hline Country & F & \% \\
\hline United States & 19 & 26.39 \\
\hline The Netherlands & 9 & 12.5 \\
\hline Norway & 6 & 8.3 \\
\hline Australia & 5 & 6.9 \\
\hline Belgium & 5 & 6.9 \\
\hline Canada & 4 & 5.55 \\
\hline Germany & 3 & 4.17 \\
\hline New Zealand & 3 & 4.17 \\
\hline United Kingdom & 3 & 4.17 \\
\hline Cyprus & 2 & 2.8 \\
\hline Finland & 2 & 2.8 \\
\hline France & 2 & 2.8 \\
\hline Taiwan & 2 & 2.8 \\
\hline Chile & 1 & 1.38 \\
\hline Denmark & 1 & 1.38 \\
\hline Egypt & 1 & 1.38 \\
\hline Hungry & 1 & 1.38 \\
\hline Hong Kong & 1 & 1.38 \\
\hline Poland & 1 & 1.38 \\
\hline Israel & 1 & 1.38 \\
\hline Grand Total & 72 & 100 (rounded) \\
\hline & &
\end{tabular}


Table 3b. Distribution in Terms of Countries

\begin{tabular}{lccccc}
\hline Countries & $\mathbf{2 0 1 5}$ & $\mathbf{2 0 1 6}$ & $\mathbf{2 0 1 7}$ & $\mathbf{2 0 1 8}$ & $\mathbf{f}$ \\
\hline United States & 4 & 2 & 5 & 8 & 19 \\
\hline The Netherlands & 3 & 4 & 2 & & 9 \\
\hline Norway & & 1 & 1 & 4 & 6 \\
\hline Australia & 1 & & 3 & 1 & 5 \\
\hline Belgium & 2 & & 3 & & 5 \\
\hline Canada & 2 & 1 & & 4 & 4 \\
\hline Germany & 1 & 1 & & 1 & 3 \\
\hline New Zealand & & 1 & & 2 & 3 \\
\hline United Kingdom & 1 & 2 & & & 3 \\
\hline Cyprus & 1 & & & 1 & 2 \\
\hline Finland & 1 & 1 & & & 2 \\
\hline France & 1 & 1 & & & 2 \\
\hline Taiwan & 1 & 1 & & & 2 \\
\hline Chile & & & & 1 & 1 \\
\hline Denmark & 1 & & & & 1 \\
\hline Egypt & & & & 1 & 1 \\
\hline Hungry & & & 1 & 1 \\
\hline Hong Kong & & & & 1 \\
\hline Poland & & & & 1 \\
\hline Israel & & & & 1 \\
\hline
\end{tabular}

Table $3 \mathrm{ab}$ on the distribution of articles in terms of countries revealed that most of the studies in program evaluation were done in the United States with frequency of $19(26.39 \%)$ in 2017 and 2018, the Netherlands with frequency of 9 (12.5\%) in 2016 but a decreased in 2017, and Norway with frequency of 6 (8.3\%) with most of the studies done in 2018. There is a steady increase in the interest of researchers on the field of study. It is assumed that the reason for less number of publications compared in the Netherlands in 2017 is that we are still in 2017. When program evaluation is considered, it is interestingly noted that Chile, Denmark, Egypt, Hungry, Hong Kong, Poland, and Israel were the countries where least number of studies have been done with 1 article each within the scope of the research.

\subsection{Distribution of Data Collection Techniques in the Scope of This Research}

The distribution of data collection techniques as shown in Table 4.

Table 4. Data Collection Techniques

\begin{tabular}{lcc}
\hline Data Collection Techniques & F & \% \\
\hline Interviews & 30 & 41.67 \\
\hline Literature Scanning & 23 & 31.9 \\
\hline Analysis of Documents & 12 & 16.67 \\
\hline Questionnaires & $\mathbf{7}$ & 9.7 \\
\hline Grand total & 72 & 100 (rounded) \\
\hline
\end{tabular}


Table 4 revealed that $30(41.667 \%)$ of the program evaluation were done through interview technique, $23(31.9 \%)$ were done through literature scanning, 12 (16.67\%) were done through analysis of document, and 7 (9.7\%). This finding revealed that the most used data collection technique was through interview.

\subsection{Distribution of Data Collection Method from the Studies in the Scope of This Research}

The distribution of data collection method used in the program evaluation in the scope of the research is given in Table 5

Table 5. Distribution of Data Collection Method

\begin{tabular}{lcc}
\hline Data Collection Method & f & \% \\
\hline Qualitative Method & 47 & 65.28 \\
\hline Quantitative Method & 11 & 15.28 \\
\hline Mixed Method & 14 & 19.44 \\
\hline Grand total & 72 & 100 (rounded) \\
\hline
\end{tabular}

Table 5 revealed that greater part of the studies in the scope of the research $(n=47)$ were fulfilled through a qualitative method. 11 of the studies, however were done through quantitative method, while 14 of the studies was through the use of mixed method of qualitative and quantitative were preferred.

\section{Distribution of Sample in the studies}

The sample used in the studies $(n=72)$ was composed of the following participants: student teachers on practice, prospective teachers, pre-service teachers, lower-level teachers, in-service teachers, full-teachers, female teachers, educators, program teachers, lecturers, and undefined, students and student groups. The array of the sample data collected from the studies are as follows:

Teachers Category: 190 pre-service teachers, 102 full-teachers, 297 full-teachers, 180 fullteachers, 202 full-teachers, 106 full-teachers, 1866 full-teachers, 6428 educators, 15 fullteachers, 102 in-service teachers, 43 full-teachers, 70 full-teachers, 37 full-teachers, 254 fullteachers, 9 full-teachers, 8 full-teachers, 74 full-teachers, 1008 full-teachers, 40 lecturers, 14 lecturers, 495 full-teachers, 179 full-teachers 79 pre-service teachers, 88 full-teachers, 13 fullteachers, 12 prospective-teachers, 30 full-teachers, 163 pre-service teachers, 83 in-service teachers, 45 full-teachers, 499 full-teachers, 322 student-teachers on practice, 22 full-teachers, 18 lower-level teachers, 2 program teachers, 248 full-teachers, 300 in-service teachers, 2 fullteachers, 359 in-service teachers, 30 female-teachers, 97\% teachers, $72 \%$ teachers, $8 \%$ teachers, $9 \%$ teachers, $87 \%$ teachers, $57 \%$ teachers, $80 \%$ teachers, $77.4 \%$ teachers, $3 \%$ teachers, $62 \%, 10 \%$ teachers, $75 \%$ teachers, $30 \%$ teachers.

Students Category: 30 students, 20000 students, 5724 students, 1336 students, 133 students, 20 students, 11844 students, 2589 students, 154 students, 204 students, 5000 students, 8500 students, 93 teams of students, 10 student groups, 106 students, 70000 students, 299 students, 60 kindergartens.

Schools \& others: 150 schools, 20 departments, 6 schools, 2 schools, 27 skills 
Table 6a. Distribution of Sample Types

\begin{tabular}{lcc}
\hline Sample & $\mathbf{F}$ & $\mathbf{\%}$ \\
\hline Full-Teachers & 24 & 32 \\
\hline Students & 17 & 22.67 \\
\hline Undefined & 13 & 17 \\
\hline In-Service Teachers & 4 & 5.33 \\
\hline Pre-Service Teachers & 3 & 4 \\
\hline Schools & 3 & 4 \\
\hline Lecturers & 2 & 2.7 \\
\hline Departments & 1 & 1.33 \\
\hline Educators & 1 & 1.33 \\
\hline Lower-level Teachers & 1 & 1.33 \\
\hline Female Teachers & 1 & 1.33 \\
\hline Program Teachers & 1 & 1.33 \\
\hline Prospective Teachers & 1 & 1.33 \\
\hline Skills & 1 & 1.33 \\
\hline Teaching-Practice Teachers & 1 & 1.33 \\
\hline Kindergartens & 1 & 1.33 \\
\hline Grand total & 75 & 100 (rounded) \\
\hline
\end{tabular}

Table 6b. Distribution of Sample Collected

\begin{tabular}{lcc}
\hline Class Interval & F & \% \\
\hline $1-99$ & 32 & 42.66 \\
\hline $100-199$ & 9 & 12 \\
\hline $200-299$ & 5 & 6.66 \\
\hline $300-399$ & 3 & 4 \\
\hline $400-499$ & 2 & 2.66 \\
\hline Over 500 & 11 & 14.66 \\
\hline Undefined & 13 & 17.33 \\
\hline Grand total & 75 & 100 (rounded) \\
\hline
\end{tabular}

Table 6a were the sample of the participants that were used in the studies within the scope. As analyzed, the sample on full-teachers has the highest frequency of $24(32 \%)$ and the students with a frequency of $17(22.67 \%)$. Others are the in-service teachers with a frequency of 4 $(5.33 \%)$, pre-service teachers with a frequency of $3(4 \%)$, lecturers with a frequency of 2 $(2.7 \%)$, while others have $1(1.33 \%)$ frequency each as shown in the table.

It is noted in table $6 \mathrm{~b}$ that the sample with class interval of 1-99 was at a frequency of 32 (42.66\%). Samples at interval of 100-199 was at a frequency of 9 (12\%). Samples with class interval of 200-299 was at a frequency of 5 (6.66\%). Samples with class interval of 300-399 was at a frequency of $3(4 \%)$. Samples with class interval of 400-499 was at a frequency of 2 $(2.66 \%)$. Samples with class interval of over 500 was at a frequency of $11(14.66 \%)$. Samples that were undefined was at a frequency of $13(17.33 \%)$. The frequency grand total was 75 with a percentage of $100 \%$ rounded. 


\section{Discussion and Conclusion}

In this study, it is aimed to specify the trends regarding the studies carried out in program evaluation in which a content analysis was done, investigating articles published on the content evaluation of programs between the years 2013-2018 in Science Direct Data Base journals, were analyzed. The research was conducted through literature review of published articles. To provide a comprehensive review of all the studies $(n=30,412)$, the researchers used a careful selection criterion with limitations to finally reached $(n=72)$ studies used in this study. Based on the distribution of the investigated articles related to the research as considered, it can be noted that the studies were mostly done in 2015 and 2018. The findings also showed that more researchers are interested in the field under study.

When the distribution of the investigated subjects was considered, it was noticed that most of the studies on program evaluation were mostly done in teacher education and educational research. Teacher education has the highest number of articles $(n=23)$, while Mathematics was the least $(n=1)$. The result shows that very limited number of studies were done in physical education, Guidance and Counselling and mathematics. It was suggested that the studies in the field of Physical education, Guidance and Counselling and mathematics are taken more seriously.

The distribution in terms of countries revealed that United States has the highest number of publications $(n=19)$. The Netherlands had $(n=9)$ publications. Those countries with limited number of studies in the subject matter were done in Chile, Denmark, Egypt, Hungary, Hong Kong, Poland and Israel with $(\mathrm{n}=1)$ article each.

The most used data collection techniques in program evaluation was the interviews $(n=30)$, literature scanning $(n=23)$, analysis of documents $(n=12)$, The questionnaire technique $(n=2)$ was the least used. The highest method used was the qualitative with a frequency of 47 $(65.28 \%)$, then the mixed method followed with a frequency of $14(19.44 \%)$, and the least used was quantitative method with a frequency of $11(15.28 \%)$ all within the scope of the study.

The investigation on the sample types in program evaluation revealed that the full-teachers were the highest participants with a frequency of $24(32 \%)$. The next sample of participants were the students with a frequency of $17(22.67 \%)$. Others include: undefined $13(17 \%)$, inservice teachers $4(5.33 \%)$, pre-service teachers $3(4 \%)$, schools $3(4 \%)$, lecturers $2(2.7 \%)$, departments $1(1.33 \%)$, educators $1(1.33 \%)$, lower level teachers 1 (1.33), female teachers 1 $(1.33 \%)$, program teachers $1(1.33 \%)$, skills 1 (1.33\%), teaching practice teachers $1(1.33)$, kindergartens $1(1.33 \%)$,

The investigated samples were put in to tables of class intervals, frequency and percentage. Samples with class interval of 1-99 were at a frequency of 32 (42.66\%), Samples with class interval of 100-199 were at a frequency of 9 (12\%). Samples with class interval of 200-299 were at a frequency of 5 (6.66\%). Samples with class interval of 300-399 were at a frequency of $3(4 \%)$. Samples with class interval of 400-499 were at a frequency of $2(2.66 \%)$. Samples with class interval of 500 and above were at a frequency of $11(14.66 \%)$. The samples that were undefined were at a frequency of $13(17.33 \%)$. The research revealed that a total of 75 samples were used in the studies at $100 \%$ rounded value. According to research results, full teachers and students were mostly used as participants in the research on program evaluation. 


\section{References}

Berrang-Ford J. D., \& Ford J. Paterson. (2011). Are we adopting to climate change?. Global Environment change, 21, 25-33

Brain, M. (2014). What is teaching?. USA: Permalink Publishers

Burns, R. (2000). Introduction to research methods. ( $4^{\text {th }}$ ed.). London: Sage

Cai, J., \& Cirillo, M. (2014). What do we know about reasoning and proving? Opportunities and missing opportunities from curriculum analyses. International Journal Research, 64, $132-140$

Caswell, H. L., \& Campbell, D. (1935). Curriculum Development. New York: American Book Company

Cheng, C. (1997). Multi-models of quality in Education. Quality Assurance in Education, 5(1), 212-231

Clemente, M., Ramirez, E., \& Dominguez, B. (2000). The selection of contents in school projects in Spain. Curriculum Inquiry, 30(3), 295-317

Coakes, S. J., \& Steed, L. (2007). SPPS Version 14.0 for windows: Analysis without anguish. Milton: John Wiley \& Sons

Cohen, L., Manion, L., \& Morrison, K. (2011). Research methods in education ( ${ }^{\text {th }}$ ed.). London: Routledge

Culbertson, H. M., \& Sumerick, N. (1976, may 19). Cloaked attribution. What does it mean to Readers?. ANPA News Research Bulletin, 3

Eisner, E. W. (2002). Those who ignore the past...12 'easy' lessons for the next millennium. Journal of curriculum studies, 32(2) 343-357. Retrieved from: http://dx.doi.org/10.1080/002202700182808

Evening, M. L. (2001). Media education Ile-Ife. University of Ife. Press Limited

Glaser, B., \& Strauss, A. (1967). The discovery of grounded Theory. Strategies for qualitative research. Chicago: Aldine

Guba, E. S., \& Lincoln,Y. S. (1994). Competing paradigms in qualitative research, 105-117. London Sage

Gudmundsdottir, S. (1990). Values in pedagogical content knowledge. Journal of Teacher Education, 41(3), 44-52. Retrieved from: http://dx.doi.org/10.1177/002248719004100306

Jones, K. O., \& Reid, J. M. V. (2007). Modifying teaching to address thinking styles. ACM International conference proceedings series, vol. 285, proceedings of the 2007 International Conference on computer systems and technologies. Retrieved from: http://dx.doi.org/10.1145/1330598.1330682

Skinner, B. (1964). Why we need teaching machine in educational technology. New York: Julia Klaus Ethrow Publications

Stephen, G. (2014). Soft skills assessment: Theory development and the research agenda. International Journal of lifelong Education, 33(4), 455-471 
Strauss, A., \& Corbin, J. (1998). Basic of qualitative research: Techniques and procedures for Developing grounded theory ( $2^{\text {nd }}$ ed.). Thousand Oaks, CA: Sage

Leathwood, C., \& Phillips, D. (2000). Developing Curriculum evaluation research in higher education process: Politics and practicalities. Higher Education, 40, 313-330

Lincoln, Y. S., \& Guba, E. G. (1985). Naturalistic inquiry. Beverly Hills, CA: Sage

Munby, H. (1990). Metaphorical expressions of teachers' practical curriculum knowledge Journal of curriculum and supervision, 6(1), 18-30

Ratsoy, E. W., \& Bing, Z. (1999). Students participation in university governance. The Canadian Journal of Higher Education, 29(1), 1-26

\section{Biodata of the Corresponding Author}

Cigdem Hursen works as an associate professor at Near East University. In October 2013, she was appointed to be the chairperson of the department of Measurement and Evaluation of Near East University, Institute of Educational Sciences. In 2018, she was appointed to be the chairperson of the department of Education Sciences of Near East University. 


\title{
FLIPPED CLASSROOM IN LANGUAGE STUDIES: A CONTENT ANALYSIS OF RECENT ARTICLES
}

\author{
Hana Dler Ahmed ${ }^{1}$, Gulsum Asiksoy ${ }^{2, *}$ \\ ${ }^{1}$ Department of Computer Education and Educational Technology, Ataturk Education Faculty, Near East \\ University, North Cyprus, Via Mersin 10, Turkey, hana.majeed90@yahoo.com \\ ${ }^{2}$ Department of Computer Education and Educational Technology, Ataturk Education Faculty, Near East \\ University, North Cyprus, Via Mersin 10, Turkey, gulsum.asiksoy@ neu.edu.tr \\ Correspondence: gulsum.asiksoy@ neu.edu.tr ; Tel.: +90 (392) 2236464
}

\begin{abstract}
The concept of the flipped or inverted classroom has become a growing technological advancement in the field of instructional education. It is a growing instructional approach, also known as a pedagogical approach in which the standard, or the conventional pattern of classroom is altered. The traditional and commonly known approach is reversed by providing the instructional contents to the students outside the boundaries of the classroom. The actual classroom is replaced by videos of course contents to be watched at home by students while the students converge in the classroom for activities that help ingrain the learnt concepts. Lately, quite a lot of studies have been conducted on the flipped classroom in different subjects of study. In this research, we will evaluate the significance of the flipped classroom based on its application to language studies and learning. A total of 20 papers were carefully selected from this field and thoroughly examined for the purpose of the research. It was concluded that the flipped classroom has gained major significance in several fields of study including hands-on fields like medicine, nursing and engineering. This research is a comprehensive pilot to instructors and researchers alike in the quickly growing field of flipped classroom.
\end{abstract}

Keywords: flipped classroom, inverted classroom technology, education, content-analysis

\section{Introduction}

Quite a lot of internet dependent technologies have been introduced to our day-to-day lives, with them gaining improved level of acceptance over time (Sams, 2012). Many of such technologies have introduced interactions and multimedia features that improve learning (Avci, Vasu, Oliver, Keene \& Fusarelli, 2014). Due to the pivotal positioning of language in learning, educational and instructional technologies have also gained application in the presentation of language course contents to students by the instructor (Hsieh, Wu \& Marek, 2017). This gives the students a privilege to study the learning materials ahead of the classroom session while the usual classroom session is majorly used to elaborate on the ideas learnt previously and obtain a deeper understanding of associated contents by the use of group discussion or inquiries and tackling of problems as guided by the instructor. It indirectly moves the homework and other activities into the classroom while the lecture session is made into video contents for the students to watch online at home, contrary to the structure of traditional learning environment (Asiksoy \& Ozdamli, 2016). Computer based approaches would be applied to perform lexical analysis of the reviewed papers with the introduction of minor statistical approaches, through which we will obtain clear and reliable information, thus making feasible recommendations through the use of content analysis. 
The following are the design principles required for the flipped classroom:

- Introducing students to the primary knowledge ahead of class activities,

- Motivates students in preparation for the class activities by watching online lectures,

- Structuring the evaluation methods,

- Bringing a connection between activities performed within the classroom and those performed outside the classroom,

- Provision of appropriate guidance to the students,

- Helps students to form a community of learners,

- Provides quick reaction or feedback about practice work,

The benefits of flipped classroom approach appear to be many, as it provides 'beyond the classroom' form of learning where students learn in the comfort of their homes at acceptable paces. Also, while engaged in discussions and reviews with the instructor, they enjoy the privilege of having a personal time with the instructors (Mate \& Salinas, 2014; Roach, 2014).

Consequently, the paper is organized as follows. We examine previous work done by researchers in the fields of flipped learning, language study and content analysis approach. Following this, we propose a theory in the methodology in order to fill the gap of research in content analysis and flipped learning when applied to language learning. We conclude with the impacts, the recommendations and the research conclusion. Some existing studies conducted on the application of flipped classroom on language study in education have been examined. A review of them are summarized here.

Chen Hsieh, Wu and Marek (2017), employed Wen's Output-driven/Input-enabled model in order to setup a complete oral teaching course in having an online section for written and verbal communication. For which the LINE application was used on mobile devices. It was gathered from the results that the theory dependent flipped mode of instruction had a positive effect on the motivation of the 'students', improved their use of idiomatic expressions in the classroom, as well as their general idiomatic knowledge. Also, Hung (2015), made an attempt at flipping the English language classroom in order to improve active learning. The study sought to identify the effects of flipping the classroom such as performance differences, disposition to learning and the level of participation by the students using three approaches to flipped classroom. The results showed that the flipped classroom approach had more effectiveness on the learning of the participants. Evaluating participation, the authors had 2 flip categories (flip and semi-flip) with 26 and 24 participants respectively. The mean of their participation was recorded as well as the standard deviation and evaluated with t-tests as seen on Table 1.

Table 1. Descriptive Statistics and İndependent Samples T-Test Results for Comparing Students' Study Time and Effort in the Structured Versus Semi-Structured Flipped Classrooms

\begin{tabular}{llllrrr}
\hline & Group & $\mathbf{N}$ & Mean & $\boldsymbol{S D}$ & $\boldsymbol{t}$ & \multicolumn{1}{c}{$\boldsymbol{P}$} \\
\hline Study time in minutes & Flip & 26 & 68.08 & 24.98 & 2.78 & $.008^{*}$ \\
\hline & Semi-flip & 24 & 53.33 & 19.71 & & \\
\hline Number of attempts for videos & Flip & 26 & 2.31 & 0.68 & 2.30 & $0.26^{*}$ \\
\hline & Semi-flip & 24 & 1.75 & 0.74 & &
\end{tabular}

Note: significance $* \mathrm{p}<.05$ 
It could be deduced from Table 1 that increased participation level was enjoyed by students of the flipped above those of students in the semi flipped classroom with a confidence level of .05 . Thus promoting the rationale that, more than the flip, the structure of the flipped classroom also plays a significant role in the participation level of the participants, suggesting the evident advantages of the application of the flipped teaching approach to language learning.

\subsection{Flipped Learning}

Considering the instances found in various research works, it is certain that the flipped classroom model has gained wide application in various fields.

In (Rotellar \& Cain, 2016), the authors recognized reasons why flipped learning is a more effective approach to learning, flipped classroom reduces academic imbalances, makes students more accountable for their performances while increasing their learning. They presented evidence of the improved academic performance caused by flipped learning in a pharmacy education class in which students' grades upped from 21 students with A, 66 students with $\mathrm{B}, 12$ students with $\mathrm{C}$ and 1 student with $\mathrm{F}$ (obtained during traditional teaching approach) to 52 students with A, 44 students with B, 4 students with C, and no student with F. Also, they present unanswered questions requiring further study in flipped classroom; for courses where the introduction of flipped classroom affects the entire curriculum, a pressing question could be "how to establish if novel characteristics exist that can forecast the success of the participating students?" another question proposed by the authors is "will graduates of a flipped classroom possess the understanding of basic facts of the flipped course?". Thirdly, the authors proposed the question "the possibility of implementing strategies and techniques that are more effective and productive within flipped classroom".

As recognized, the following are the four pillars of the F.L.I.P.TM model (García-Peñalvo, Fidalgo-Blanco, Sein-Echaluce \& Conde, 2017);

- Flexible environment,

- Learning culture,

- Intentional content,

- Professional educator.

\subsection{Content Analysis}

This is a research approach where written, spoken or visual data is described either by numerical descriptors (quantitative) or text based descriptors (qualitative). Due to its versatility, it can be applied to recent materials gathered by researchers and academicians in an attempt to categorize open-ended responses obtained from interviewees. It can be applied to; questionnaires, print media, visual media etc. Of all its advantages, the most notable is that it can be applied to social occurrences non-invasively. The following are pivotal questions that must be considered in every content analysis (Krippendorff, 2004);

- Which data is to be analyzed?

- How are they defined?

- From what population are they drawn?

- What is the relevant context?

- What are the limits of the analysis?

- What is being measured?

In the basic form, content analysis evaluates distinct characteristics (such as word frequency) of the text contained in the document. This approach has limited analytical effectiveness as meaning of words is largely dependent on neighboring words in the context. 


\section{Methodology}

In this paper, we have performed content analysis on 20 selected publications detailing on flipped classroom in the language teaching setting. For this, we have selected only recent publications ranging from year 2015 till date 2018. Certain criteria for this research work were inherited from state of the art approaches and generally accepted parameters within the field, such criteria as spelt out in previous works are;

1. What are the years of publication by papers?

2. What is the number of articles by country of publication?

3. What instructional models were used in the flipped study?

4. What areas of flipped classroom studies was researched?

5. What technology, tools or online platform have been used for implementing the flipped classroom?

6. What are the impacts of implementing the flipped classroom on the learning of the students?

7. What are the challenges of applying the flipped classroom approach?

\subsection{Number of Articles by Year of Publication}

A total of 20 articles were selected for the purpose of this research. As seen in Table 2, 6 were carefully selected from year 2015, 9 were selected from the year 2016, 3 were selected from year 2017 and the remaining 2 are the most recent journals. Selected from among year 2018 publications.

Table 2. The Distribution of the Number of articles by years

\begin{tabular}{lc}
\hline Years & Frequency $(\mathbf{f})$ \\
\hline 2015 & 6 \\
\hline 2016 & 9 \\
\hline 2017 & 3 \\
\hline 2018 & 2 \\
\hline
\end{tabular}

\subsection{Number of Articles by Country of Publication}

The articles selected were implemented in multiple countries in order to investigate the effects of the flipped classroom on a regional basis, with 1 paper having a broad scope of implementation in 3 countries (USA, China and Macau). Taiwan had the highest contribution of 5 papers between years 2015 and 2018. Table 3 contains a complete distribution of the resources by the Country in which the implementation was conducted. 
Table 3. Distribution of the Articles by the Country

$\begin{array}{ll}\text { Country } & \text { Frequency (f) }\end{array}$

\begin{tabular}{ll}
\hline Taiwan & 5 \\
\hline USA & 2 \\
\hline Korea & 1 \\
\hline Turkey & 1 \\
\hline Japan & 1 \\
\hline Russia & 1 \\
\hline Saudi Arabia & 2 \\
\hline Singapore & 1 \\
\hline Spain & 1 \\
\hline China & 2 \\
\hline Egypt & 1 \\
\hline Indonesia & 1 \\
\hline Macau & 2 \\
\hline South Korea & 1 \\
\hline
\end{tabular}

\subsection{Instructional Model Used in the Flip Study}

These are the set of guidelines on which instructors base their teaching approaches. In the reviewed papers, various models were employed distinctly while some made use of a combination of models. The following models were employed;
a. Concept attainment model
b. Integrative model
c. Lecturer discussion model
d. Direct instruction model
e. Problem based

\subsection{Areas of Flipped Study That was Researched}

The following are the areas that were researched in the selected papers.

Table 4. Area of Flipped Study That was Researched

\section{Area}

Frequency (n)

\begin{tabular}{ll}
\hline University Level English & 6 \\
\hline English as Foreign Language & 3 \\
\hline English for Vocational Education & 1 \\
\hline Secondary School & 3 \\
\hline English for Specific Purposes & 2 \\
\hline English for Academic Purposes & 1 \\
\hline
\end{tabular}




\subsection{Technology, Tools or Online Platform Used in the Implementation}

Various tools were used in the selected papers for the purpose of the research as required by the authors.

Table 5. Frequency of Usage of Technology in Papers

Technology/Tool/Online Platform

Frequency (n)

\begin{tabular}{ll}
\hline Television sitcom & 1 \\
\hline LINE mobile app & 1 \\
\hline Shared Video & 8 \\
\hline Edmondo website & 1 \\
\hline YouTube & 3 \\
\hline Screenomatic & 1 \\
\hline Padlet & 1 \\
\hline Moodle & 1 \\
\hline WebQuest & 1 \\
\hline TED-Ed & 1 \\
\hline Screencast & 1 \\
\hline Keynote & 1 \\
\hline Doctopus & 1 \\
\hline
\end{tabular}

\subsection{Impacts of Flipped Classroom on Students Learning}

After the review of the selected papers, the following impacts of the flipped classroom in language teaching were gathered;

Table 6. Showing the Impact of Flipped Classroom on Participants

\begin{tabular}{ll}
\hline Impact & Frequency (f) \\
\hline Enhanced student engagement & 3 \\
\hline Increased student performance & 5 \\
\hline Strengthened course design & 1 \\
\hline Improved learning attitudes & 3 \\
\hline Enhanced participants' motivation & 3 \\
\hline Improved participants' knowledge & 1 \\
\hline Improved learner autonomy & 1 \\
\hline Increased students' interaction & 1 \\
\hline
\end{tabular}




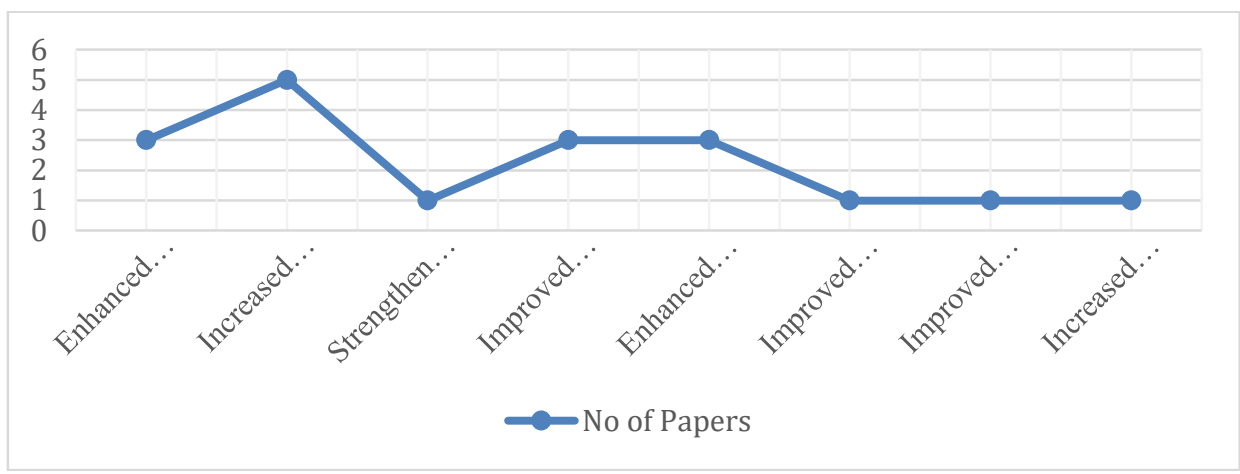

Figure 1. Showing the Impact of Flipped Learning on Students

\subsection{Challenges of Applying the Flipped Classroom Approach}

Regardless of the obvious benefits of the flipped classroom approach, some certain challenges are inherent. As identified during the study, they are listed in the following table.

Table 7. Showing the Various Challenges in the Implementation of Flipped Classroom as Specified in the Papers

\section{Challenges}

Frequency (f)

\begin{tabular}{ll}
\hline Approach best reserved for teaching and learning procedural knowledge & 3 \\
\hline Student may receive insufficient input, output due to time constraint & 1 \\
\hline Students may prefer the traditional approach & 3 \\
\hline Preparation and perception of students & 1 \\
\hline Lack of internet access & 3 \\
\hline Students may not watch videos & 3 \\
\hline Passive approach & 2 \\
\hline Challenge of producing material & 3 \\
\hline
\end{tabular}

\section{Discussion and Conclusion}

Due to the fact that changes now exist in the teaching landscape with the integration of technology, changes also are expected in the effectiveness of educationists and academicians. Such powerful change has been investigated in this paper. From the paper, it was gathered that most of the implementations of the flipped classroom was done in Taiwan, while the most significant impact of flipped classroom was 'improvement in performance' with an impact ratio of $27.7 \%$ among 8 noted impacts. Also, some of the major challenges experienced by the researchers in the study are the possibility of students to be lazy and not watch scheduled videos at home, possible lack of required technological infrastructure, possibility of some courses not being conformable to the flipped approach and the actual fact that some students may absolutely dislike the flip idea.

\section{References}

Al-Harbi, S. S., \& Alshumaimeri, Y. A. (2016). The flipped classroom impact in grammar class on EFL Saudi secondary school students' performances and attitudes. English Language Teaching, 9(10), 60-80. 
Alsowat, H. (2016). An EFL flipped classroom teaching model: Effects on English language higher-order thinking skills, student engagement and satisfaction. Journal of Education and Practice, 7(9), 108-121.

Asıksoy, G., \& Ozdamlı, F. (2016). Flipped Classroom adapted to the ARCS Model of Motivation and applied to a Physics Course. Eurasia Journal of Mathematics, Science and Technology Education, 12(6), 1589-1603. doi: http://10.12973/eurasia.2016.1251

Avci, Z. Y., Vasu, E. S., Oliver, K., Keene, K. A., \& Fusarelli, B. (2014). Utilization of online technologies in mathematical problem solving at high school level: Student and teacher perceptions. World Journal on Educational Technology, 6(2), 203-217

Basal, A. (2015). The implementation of a flipped classroom in foreign language teaching. Turkish Online Journal of Distance Education, 16(4), 28-37

Chen Hsieh, J. S., Wu, W.-C. V., \& Marek, M. W. (2017). Using the flipped classroom to enhance EFL learning. Computer Assisted Language Learning, 30(1-2), 1-21. doi: http://10.1080/09588221.2015.1111910

Chilingaryan, K., \& Zvereva, E. (2016). Methodology of flipped classroom as a learning technology in foreign language teaching. Procedia-Social and Behavioral Sciences, 237(21), 1500-1504.

Correa, M. (2015). Flipping the foreign language classroom and critical pedagogies: a (new) old trend. Higher Education for the Future, 2(2), 114-125.

Doman, E., \& Webb, M. (2016). The flipped experience for Chinese university students studying English as a foreign language. TESOL Journal, 8(1), 102-141.

Evseeva, A., \& Solozhenko, A. (2015). Use of Flipped Classroom Technology in Language Learning. Procedia-Social and Behavioral Sciences, 206, 205-209.

García-Peñalvo, F. J., Fidalgo-Blanco, Á., Sein-Echaluce, M. L., \& Conde, M. Á. (2017). Cooperative Micro Flip Teaching,. Learning and Collaboration Technologies. Technology in Education. 4th International Conference, LCT 2017, Canada.

Hsieh, J. S. C., Wu, W. C. V., \& Marek, M. W. (2017). Using the flipped classroom to enhance EFL learning. Computer Assisted Language Learning, 30(1-2), 1-21. htpp://doi: 10.1080/09588221.2015.1111910

Hsueh-Hua, C., Chih-Yuan, W., \& Ching-Huei, C. (2018). Which students benefit most from a flipped classroom approach to language learning? British Journal of Educational Technology, 49(1), 56-68. htpp://doi: doi:10.1111/bjet.12530

Hung, H.T. (2015). Flipping the classroom for English language learners to foster active learning. Computer Assisted Language Learning, 28(1), 81-96. doi: htpp://10.1080/09588221.2014.967701

Hung, H.-T. (2017). Design-Based Research: Redesign of an English Language Course Using a Flipped Classroom Approach. Tesol Quarterly, 51(1), 180-192

Kang, N. (2015). The comparison between regular and flipped classrooms for EFL Korean adult learners. Multimedia-Assisted Language Learning, 18(3), 41-72.

Krippendorff, K. (2004). Content Analysis: An Introduction to Its Methodology. Beverly Hills: SAGE. 
Lee, G., \& Wallace, A. (2018). Flipped learning in the English as a foreign language classroom: Outcomes and perceptions. TESOL Quarterly, 52(1), 62-84.

Leis, A., Tohei, A., \& Cooke, S. (2015). The Effects of Flipped Classrooms on English Composition Writing in an EFL Environment. International Journal of ComputerAssisted Language Learning and Teaching (IJCALLT), 5(4), 37-51.

Liu, D. (2016). The Reform and Innovation of English Course: A Coherent Whole of MOOC, Flipped Classroom and ESP. Procedia - Social and Behavioral Sciences, 232, 280-286. doi: https://doi.org/10.1016/j.sbspro.2016.10.021

Mate, K. S., \& Salinas, G. (2014). Flipping primary health care: A personal story. Healthcare, 2(4), 280-283. doi: https://doi.org/10.1016/j.hjdsi.2014.10.003

Mehring, J. (2016). Present Research on the Flipped Classroom and Potential Tools for the EFL Classroom. Computers in the Schools, 33(1), 1-10. http://doi: 10.1080/07380569.2016.1139912

Roach, T. (2014). Student perceptions toward flipped learning: New methods to increase interaction and active learning in economics. International Review of Economics Education, 17, 74-84. http://doi: https://doi.org/10.1016/j.iree.2014.08.003

Rotellar, C., \& Cain, J. (2016). Research, Perspectives, and Recommendations on Implementing the Flipped Classroom. American Journal of Pharmaceutical Education, 80(2), 1-4.

Sams, J. B. A. (2012). Flip Your Classroom: Reach Every Student in Every Class Every Day 1. ed., Washington: ISTE Publishing.

Soliman, N. A. (2016). Teaching English for Academic Purposes via the Flipped Learning Approach. Procedia - Social and Behavioral Sciences, 232, 122-129. htpp://doi: https://doi.org/10.1016/j.sbspro.2016.10.036

Webb, M., \& Doman, E. (2016). Does the Flipped Classroom Lead to Increased Gains on Learning Outcomes in ESL/EFL Contexts? CATESOL Journal, 28(1), 39-67.

\section{Biodata of the Corresponding Author}

Asst. Prof. Dr. Gülsüm Aş1ksoy has completed her B.Sc degree in Physics Engineering at Ankara University. Between 1995 and 2006 she worked in private sector in the various field (computer, electronic security) as a planning engineer in Ankara, Turkey. She received her M.Sc degree in Electrical and Electronic Engineering in 2011. She received her $\mathrm{PhD}$ in Computer Education and Instructional Technology. She teaches general physics, game-based learning, gamification in education, distance education, research methods and technics courses as undergraduate and master level courses. Her research interests include flipped learning, gamification in learning and instruction, interactive simulations for teaching and learning physics, digital games and simulations and artificial neural networks. She is currently vice chair of Department of Mathematics and Science Education. 


\title{
CONTENT ANALYSIS OF GUIDANCE AND PSYCHOLOGY - SPORTS AND RELATED ARTICLES
}

\author{
Engin Baysen ${ }^{1 *}$, Philip Ezekiel Chall Dakwo ${ }^{2,}$ \\ ${ }^{1}$ Institute of Educational Sciences Faculty, Near East University, North Cyprus, Via Mersin 10, Turkey, \\ engin.baysen@neu.edu.tr \\ ${ }^{2}$ Department of Psychological and Guidance Counseling, Institute of Educational Sciences Faculty, Near East \\ University, North Cyprus, Via Mersin 10, Turkey, halldakwo0003@gmail.com \\ Correspondence: engin.baysen@neu.edu.tr ; Tel.: +09 (392) 2236464
}

\begin{abstract}
This research was conducted following a qualitative content analysis of guidance and psychology; sports and related articles between 1937- 2017, with limitations medicine, psychology, health professions, social sciences, biology, engineering, agriculture, computer science etc. Scopus database was sorted to collect the data where 93 documents were got. This article focused guidance and psychology; sports and related areas. Answers were sort for distribution of the articles according by year, source, author, affiliation, country or territory, subject area, subject sample, method, statistics, and sub areas of guidance psychology. There was inconsistency in the incremental level of the articles in guidance psychology but a significance was recorded in 2015 and 2017. The findings revealed until early 2000, most of the writers had one article or never at all. But this changed in the mid 2000 where medicine had the highest and more writers involved as the years passed till 2017. The findings also revealed that the qualitative research was used more than quantitative and mixed methods. The distribution of articles by the sub areas of guidance psychology revealed that human medicine and psychology had the most written articles, while health professions and social sciences followed in writers.
\end{abstract}

Keywords: education, psychology, guidance, sports performance

\section{Introduction}

Psychological guidance counseling addresses the emotional, social, work and physical concerns people may have at different stages, lives, focusing on typical life stresses and more several issues with which people may struggle as individuals and part as families, groups and organizers. It also attends to the needs of students, parents, guardian's professional associations and communities, as well as involves individual planning and guidance, curriculum instruction, system support and provisions of response services. They may promote student's achievement through individual consultation. Brammer and Shostrom (1977) saw counseling as a way of relating and responding to another person so that he is helped to explore himself through understanding, and also finding and using his strengths to be able to cope more effectively with making appropriate actions. Guidance and psychological counseling is expected to address the "emotion........... social, at different stages.

Similarly, sports are physical activities that go beyond competitive sports (Sports and development org). Jaiyeoba and Ademola (2014) see it as including all forms of competitive physical activities or games which, through casual or organized participation. Its aim is to use, maintain or improve physical ability and skills while providing enjoyment to participants and in some cases entertainment for spectators. It is also to maintain and improve physical activity 
and skills while providing enjoyment to participants and in some cases entertainment for spectators. It is generally recognized as a system of activities which are based in physical athleticism or physical dexterity (Wikipedia, 2017). Rush (2017) said that sports recorded the highest participation in the United States in 2010 - 2011. 55\% of high school students participated. It can positively impact children and adults, providing opportunities to get exercises and spend time with peers in healthy environment. Rush (2017) defined sports as that which can make you stronger and healthier and contributing to lower obesity rates. The department of health and human services, acknowledge that sports tend to have lower body mass index than non-sports men Encyclopedia Britannica (2009), views it as enjoyment and entertainment for spectators and a form of physical activity to contribute to physical fitness, mental well-being and social interaction which include, play, recreation, organized, casual or competitive sports and indigenous sports or games (Bucher 1979). The Oxford dictionaries (2010) view sports as any activity involving physical exertion and skills in which an individual or team competes against another or others for entertainment. They are generally understood to include physical activities that go beyond competitive sports which apparently become important in the life of young adults, especially of secondary school age where character, values and beliefs of young people are shaped (Bucher, 1979). These activities and interest provide many positive opportunities for children. However, they can also cause some problems, even though they believe that participation in sports will enhance children's school accomplishments others believe that it gets in the way of their children's achievement, whether they help or distract from achievement depends on the extent of children's involvement and the type of experience they have (Rimm, 2008), but it is generally recognized as a system of activities which are based in physical athleticism or physical dexterity (Wikipedia, 2017). Nonetheless, Rush (2017) asserted the positive impact of sports as children and adults, are provided opportunities to get exercises and spend time with peers in a healthy environment. Viewing the gravity of the deficiencies in the sports sector there is therefore the need for, "A healthy nation is always a wealthy nation", therefore pursuing "Menes Sana In capo Sano" a "healthy mind in a healthy body" for a nation as physical and mental wellbeing are pre requisite of great achievement in man's life (Sylvia, 2008). Rush (2017) viewed sports as that which can make you stronger and healthier and contributing to lower obesity rates. The department of health and human services (2017), acknowledge that athletes tend to have lower body mass index than non - athletes. But generally, sports have served and are serving as a unifying agent and an avenue where there can be gotten a cross cultural share of ideas by different nations or cities. Marriages have said to have been gotten through sports. Friendships have been developed and strengthened through it (Burt, 1998) Socially sports have served and are serving as a unifying agent and an avenue where there can be gotten a cross cultural share of ideas by different nations or cities. Marriages have said to have been gotten through it. Friendships have been developed and strengthened through it. How Guidance and psychological counseling on the other hand addresses the emotional social, work and physical concerns people may have at different stages, lives, focusing on typical life stresses and more several issues with which people may struggle as individuals and part as families, groups and organizers (Banal, 2017). It also attends to the needs of student, parents, guardian's professional associations and communities. It involves individual planning and guidance, curriculum instruction, system support and provisions of response services. They may promote student's achievement through individual consultation (Banal 2017). Brammer and Shostrom (1977) saw counseling as a way of relating and responding to another person so that he is helped to explore himself through understanding, and also find and use his strengths to be able to cope more effectively with making appropriate actions. 
Beautiful as these may be, the question is asked, have the guidance and psychological counselors worked in this direction? Secondary Schools that have a population of two hundred and fifty (250) in the final year may have only 15 of them writing physical education examination while the rest are in English, Mathematics or technical classes Sports which are synonymous to physical exercise are expected to build a healthy mind and a healthy nation. It is also expected to provide skills, athleticism, dexterity, enjoyment and entertainment. Moreover, it now serves as a means to livelihood. Example is drawn from Lionel Messi of Barcelona, Neymar of Paris Saints Germaine, Usain Bolt of Jamaica, Serena Williams of Great Britain, Samuel Etoo of Cameroon, Didier Drogba of Cote de"viore, Kanu Nwankwo and Mikel Obi of Nigeria, Victor Moses of Nigeria, Anthony Joshua Britain, who earned and are earning millions of dollars per week as their pay or salary.

Money have been invested in building facilities in the various Schools and communities, have these things been fully utilized as the students are guided and directed to meet their needs by the counselors? Schools are burnt down, injuries are sustained, equipment are damaged, officials molested, during and after sports meet, have emotions been addressed by counselors? It is on this basis that the researcher is set to assess the efficacy of guidance and psychological techniques in sports performance in secondary schools.

\section{Research Questions}

Beautiful as these may be, the question is asked, have the guidance psychologists and researchers worked in this direction with the students in all educational institutions globally especially considering the rate of article publications on the basis of year, source, author, country, subjects and affiliation? Sports which are synonymous to physical exercise are expected to build a healthy mind and a healthy nation. It is also expected to provide skills, athleticism, dexterity, enjoyment, entertainment and serves as a means to livelihood to many youths and students of various categories in the contemporary of world today. Thus, more research works need to be concentrated on this aspect of sport activity which is holding such a robust sector that have proper people and nations of the world physically, psychologically, economically and socially. It is upon these various aforementioned assertions that this study formulated the research questions as follows:

- What is the distribution of articles publications on yearly basis on Psychological guidance and sport performance?

- What are the distributions of article publications by source, author, country, subject areas and affiliation on psychological guidance and sport performance among students?

- How often is psychological guidance and sport performance mentioned in the overall sampled articles?

- To what extent are these articles practically and theoretically related to psychological guidance and sport performance?

- How related are these articles to the research topic specifically?

- What is the extent of the research methodology? (quantitatively, qualitatively or by mixed method)

\section{Significance of Study}

Economically, money is used to build facilities in various areas thus providing accessibility to the public and indirectly providing a steady sport revenue stream. Sports have always been a primary role of both participants and spectators. Today, sports are often organized, 
mechanized, marketed and administered as business, commercial interest influence virtually every decision in sports (Long \& Sanderson 2001). Wallhead and O'sullivan (2005) asserted that Sports are growing more into business. It is growing into an economic power; it is also attracting commercial interest, which could benefit from that power by influencing its organization (Wallhead \& O sullivan, 2005). Money has been invested in building facilities in the various schools and communities, but have they been fully utilized? Guidance and psychological counseling is expected to address this including the "emotion........... social, at different stages. Schools are burnt down, injuries are sustained, equipment are damaged, officials molested, during and after sports meet, have emotions been addressed? Flaws are committed in sports sector in spite of resources pump into the sector, but leaves much to be desired. Britain, America, Germany, Russia, France and so on have sunk resources into this sector and gets almost equal or equal the input. This therefore made the choice of topic necessary in order to add to knowledge in this area.

\section{Research Methodology}

Content analysis was used for this study. Articles, efficacy of psychological guidance in sports performance and related subjects were selected; medicine, social sciences, pharmacy, psychology, biology, and other relevant areas were sorted and brought together for further analysis.

Content analysis according to Encyclopedia Britannica(2009), says quality research methods is an intellectual way of categorizing qualitative textual data into similar entities, or conceptual categories to identify consistent patterns of relationships between variables or themes. It is the method used to describe systematically written, spoken or visual communications thereby providing qualitative descriptions Long and Sanderson (2001) envisaged content analysis to involve media- print, newspaper, magazines, televisions, videos, and the internet, any medium that can be recorded, reviewed is appropriate. Content analysis, is also used to analyses new materials recorded by the researchers and to classify open ended responses to interview or survey questions. Moreover, descriptive content analysis is serves as a prelude to other types of research, often in domains not previously explored. Content analysis is an end to itself and it is a method used to answer research questions about content. However, it is worth noting that the method also has in conjunction with other research strategies. Content analysis has been used to examine evolution of other academic disciplines. for example, Rush (2017) used 100 key words to classify content of articles published in two clinical psychology and two health psychology journals to characterize the most important theoretical issues facing both disciplines. Banal (2017), saw content analysis as a research method that uses a set of procedures to make valid inferences from texts. Crippen (1980) emphasis on reliability and validity. Rimm (2008), viewed it as a research technique for making replicative and valid references from data to their context. The emphasis is on data which reminds the reader that quantitative content analysis reductionist, with sampling and operational or measurement procedure that reduce communication phenomena to manageable data from which references can be drawn about the phenomena themselves.

\section{Data Collection}

The data was generated from education, psychology, guidance and sports performance, and some other relevant fields where 95 documents for a period of 81 years were obtained from the 
analyzed document by year, source, author, affiliation, country/territory and subject; this is between the years 1937 to 2017 . Each of the articles had methods, sample and statistics.

\section{Data Analysis}

The researcher used Analyzed Search Result buttons to find the distribution regarding the years range, covering the aspect of subjects, methods, samples and statistics. The 95 document result of Psychological guidance in sports performance were counted and analyzed in accordance with the research questions. The data obtained from the articles were analyzed through descriptive, inferential and undefined statistics. The data were put into tables of related subjects, methods, samples and statistics after calculating their frequencies and percentage values.

\subsection{Distribution of Article Publications on Yearly Basis on Psychological Guidance and Sport.}

Table 1. Distribution by Year

\begin{tabular}{llll}
\hline Year & & & \\
\hline 2017 \\
\hline 2015
\end{tabular}

It can clearly be seen from this Table 1 and Graph 1 that 95 documents were analyzed and only 1 article was written in the year 1937, after which 1938 to 1967 there were no articles written. But in 1968, 1997, 1980, 1981, 1987, 1989, 1991, 1994, 1997, 1998, 2002, 2007, one article each was written in the years 1986, 2001, 2002, 2003, 2005, 2009, two articles each were written while in the year 2004, three articles were written. There was increase in the number of articles in the 2008 and 2016 to four each and also increased I the subsequent years, 2006, and 2014 to five articles, this probably was an era of enlightenment to article writing and 
increase in publications. It became evident in the years, 2010 and 2012 when the articles rose to six, articles writing got improvement in 2011 to eight and nine in 2013. In the year 2015, ten articles were written while in the year 2017, twelve articles were written.

Two authors Michele, J. and Theebeem, M. wrote 3 articles each and some three, Luo, Q., Vertonghen, J., and Visscher, C., wrote 2 articles each. Most of the writers 151 of them wrote 1 article each in Scopus Index as discovered by this work in the 81 years of writing of articles. A good look at the graph and the years of publishing, one could see the graph moving up from the year 2014 to 2017 meaning that there will be more articles in years to come. From the inception in 1937, just one article was written and it took till 1968 before another article was written this entails the poor article writing habits at that period. Critically looking at the graph, one will see that it was in 1986, 2001, 2003, 2005 that 2 articles each were written in this area of study. The graph shows the growth pattern of publication rising as the years pass. The years 2006 to 2017 saw a sharp rise of articles in this area, meaning awareness of writing in this field and area of study is becoming more for researchers and academicians. Therefore, it will continue to increase as the years roll pass.

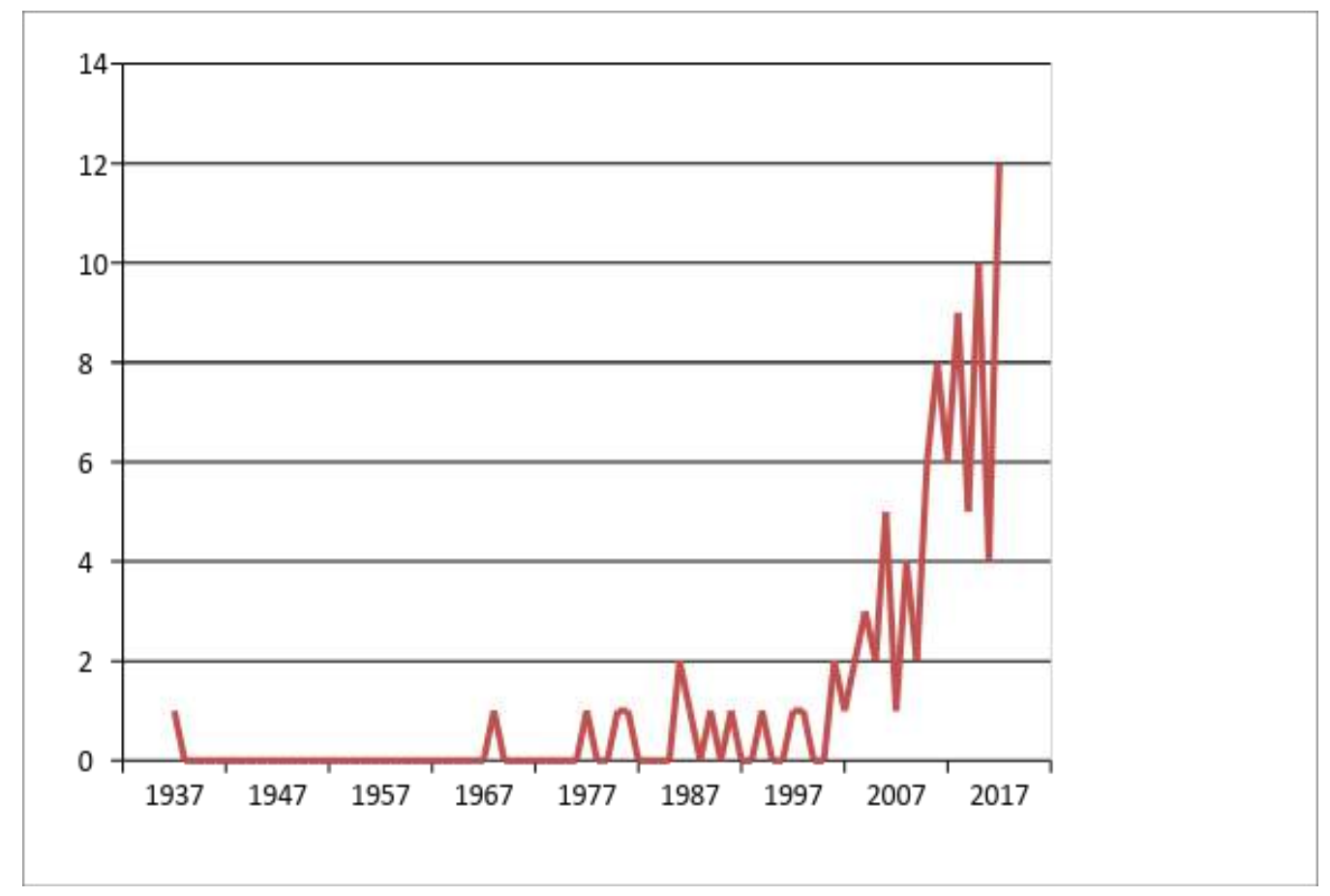

Figure 1. Distribution by Year 


\subsection{Distribution of Article by Source, Author, Country, Subject Areas and Affiliation on Psychological Guidance and Sport Performance}

Distribution of Articles by Source

Table 2. Distribution of Sources

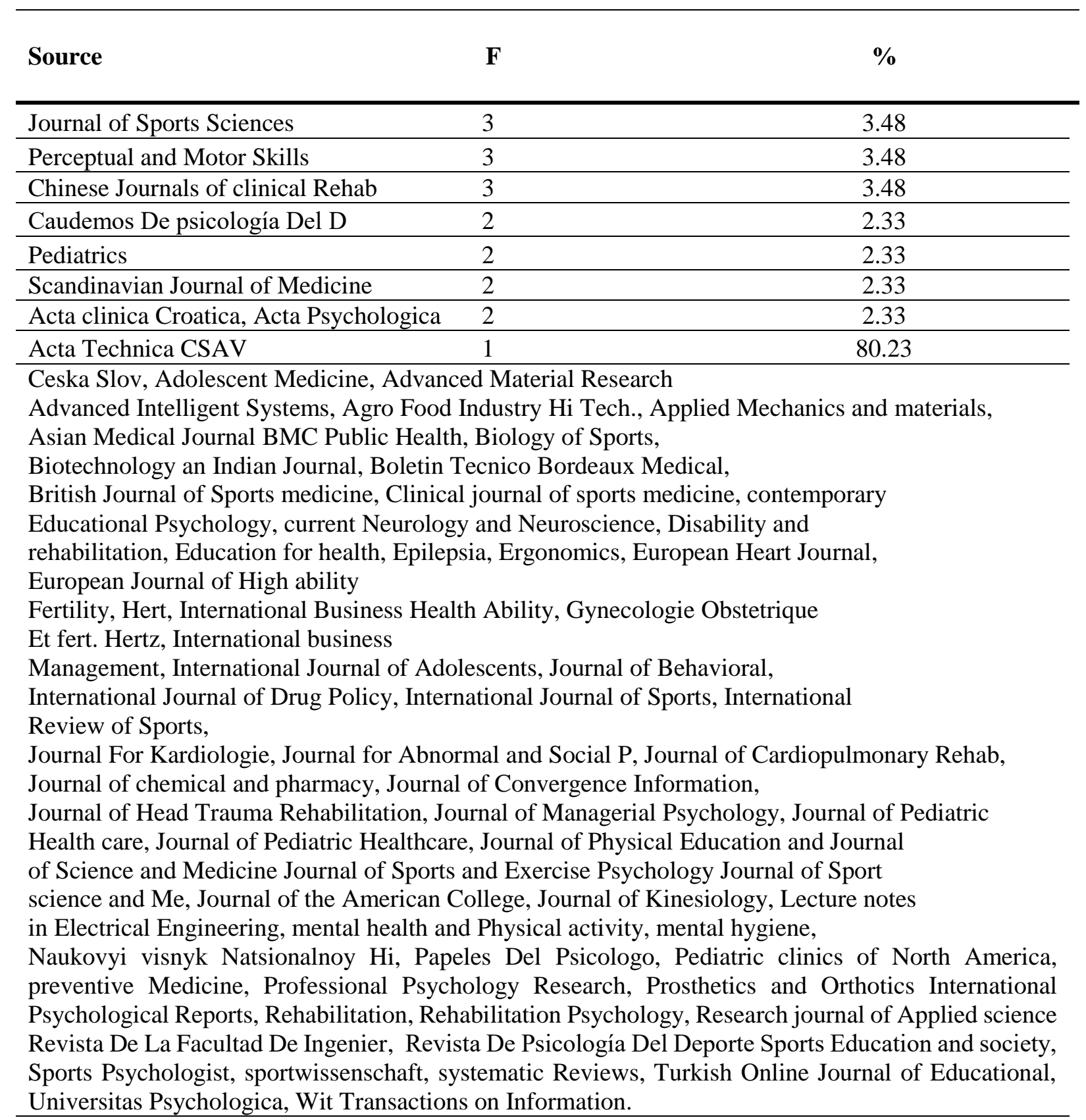

Universitas Psychologica, Wit Transactions on Information.

Grand total

Table 2. Response to sources of articles or publications in 81 years. The study reveals that psychological guidance in sports had been carried out and Egitim Arastirmalari Eurasian, journal of sports sciences, and Perceptual and motor skills had written 3 articles each, while Chinese Journal of Clinical Rehabilitation, Cuadernos De psicología Del Dep, Pediatrics, and Scandinavian each. From these articles, sports journal of sciences and Perceptual and motor skills under sports had 5 articles while medicine had 8 articles, (Chinese journal of clinical 
rehabilitation, Claude Mes De psicologia Del Dep, Pediatrics, Scandinavian journal of medicine,) Although, there might be people who had written articles in the 81 years of research but have not been able to identify them here because of space and more so most of them had an article.

\subsection{Analysis of Article by Authors}

Table 3. Distribution Authors

\begin{tabular}{|c|c|c|}
\hline Source & $\mathbf{F}$ & $\%$ \\
\hline Michele L.J & 3 & 1.8 \\
\hline Theeboom, M. & 3 & 1.8 \\
\hline Luo, Q & 2 & 1.2 \\
\hline Vertonghen, J. & 2 & 1.2 \\
\hline Visscher, C & 2 & 1.2 \\
\hline $\begin{array}{l}\text { Ahmed, MD, Akar, F, Allen, J.B, Aoyagi, } \\
\text { M. W, }\end{array}$ & 1 each & 92.6 \\
\hline Audebert, A, Axelsson K, Backhouse S.H & 151 & \\
\hline \multicolumn{3}{|c|}{$\begin{array}{l}\text { Bailes, J, Ballinger, D.A, Barker.J, Barkoukis V, Barros-Guerrero. A, Barrow } \\
\text { J.C, Berry, J, Biguet. G, Blaine, G.B, Boen F, Bogaerts A, Bovendeerdt. T.J.H, } \\
\text { Brand. R, Breslin.G, Brink M.S, Butki, B.D. Cairmey J, Caliskan, G, Camfield C. } \\
\text { Comfield P, Camire, M, Capovilla.G, Capovilla, Carmen, L.R, Carre, F, Catina.P, } \\
\text { Cavher.E, Chaabene.H, Chamari, Chang, Y.T, Chen.Z Cheour.F, Chirivella } \\
\text { E.C, Clark H.J, Clay, O.J, Clough, P.J, Cohen, A.B, Cox M.K, Crespo, M, Curran, T, } \\
\text { Dawes H, De Knop P, Dede.O, Dolan S.H, Dolenc P, Donnelly.P, Dosil J, } \\
\text { Dosil-Diaz.J, Dreer. L.E, Dudink, A, Duncan S, Echemendia, R.J, Eckerson J.M, } \\
\text { Edwards R.T. }\end{array}$} \\
\hline Grand Total & 163 & 100(rounded) \\
\hline
\end{tabular}

Table 3 accounts for articles published by authors. This reveals that Michelle. J., and Theeboom, M., wrote 3 articles each, while Luo,Q., Vertonghan, J., and Visscher,C., wrote 2 articles each within this period of 81 years. Most of the writers (151) of them had an article each in the index Scopus in these 81 years of study 


\subsection{Analysis by Affiliation}

Table 4. Distribution of Affiliation

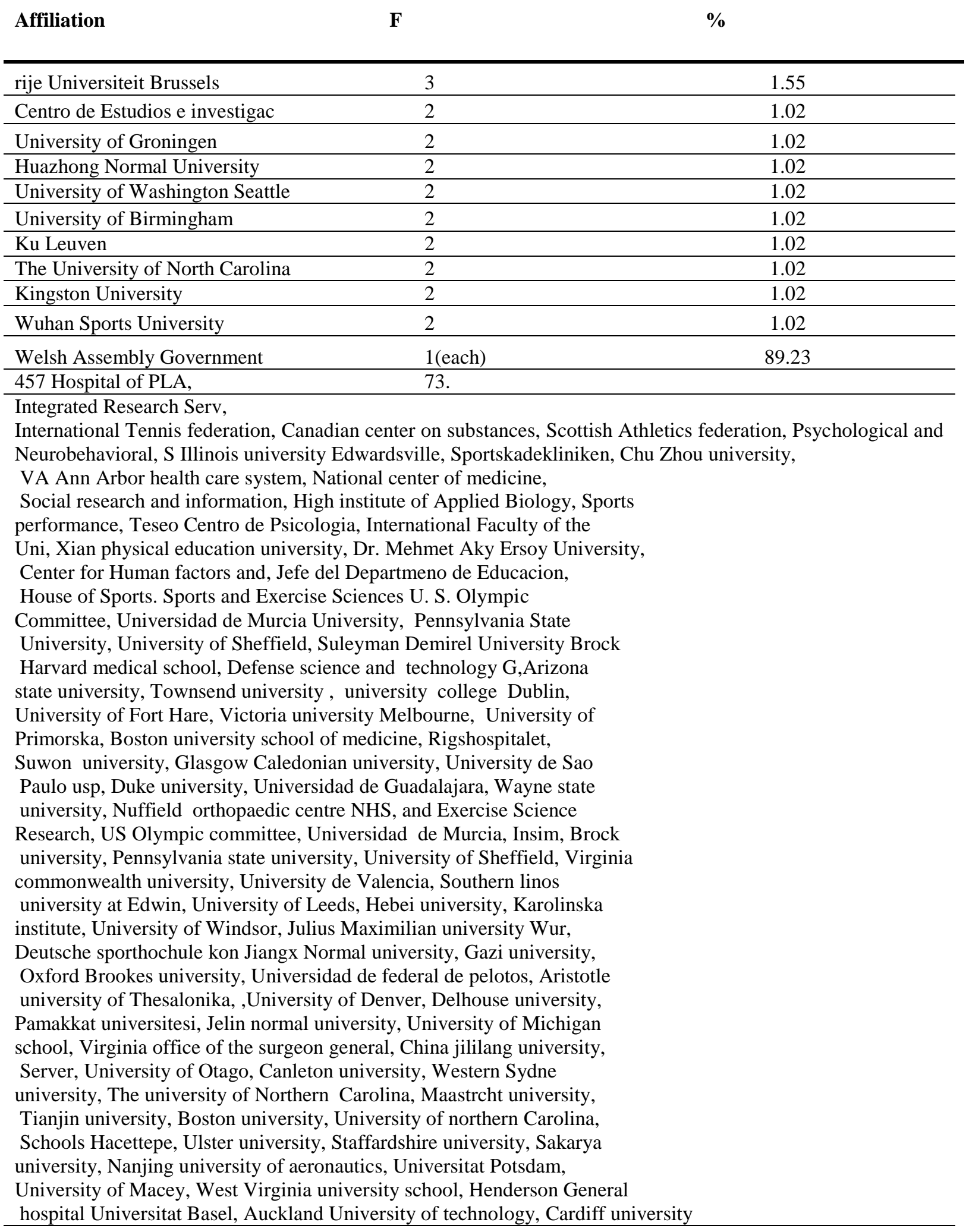


Table 4, responded to the distribution of articles by affiliation and it revealed that Virgi University Brussels published 3 articles and a frequency of $1.55 \%$ while Contro de Estudies, University of Gragningen, Huazhong Normal University, University of Washington, Birmingham, Wuhan sports, had 2 articles each published, which gave a frequency of $1.02 \%$ each giving a total of $9.23 \%$ while most other writers (73) of them had an articles each with a frequency of $89.23 \%$ for all. The research reveals that a total of 195 affiliations were recorded within the period of 81 years.

\subsection{Analysis by Country}

Table 5. Distribution of Country

\begin{tabular}{ll}
\hline Country & F \\
\hline United States & 23 \\
\hline China & 16 \\
\hline United Kingdom & 10 \\
\hline Undefined & 8 \\
\hline Spain & 6 \\
\hline Turkey & 6 \\
\hline Australia & 6 \\
\hline Belgium & 5 \\
\hline Canada & 5 \\
\hline Germany & 5 \\
\hline Netherland & 5 \\
\hline Denmark & 3 \\
\hline Ireland & 3 \\
\hline Italy & 2 \\
\hline Taiwan & 2 \\
\hline Austria, Brazil, Greece & 2 \\
\hline Japan, Mexico, New Zealand & 1 each 17 \\
\hline Oman, Pakistan, Qatar & \\
\hline Russian Federation, Singapore & \\
\hline Slovenia, South Africa, South Korea Sweden, Switzerland, \\
Tunisia & \\
\hline
\end{tabular}

Table 5 reveals the distribution of articles by countries and goes to show us that the United States had 23 articles, while china had 16 and the United Kingdom had 10. There were 8 of the article from unidentified countries. Spain and Turkey had 6 articles each as at the period of the study. Australia, Belgium, Canada and France published 5 articles each while Germany and Netherlands had 3 articles. Denmark, Ireland, Italy, Taiwan published 2 articles each. 17 of the countries including Austria, Brazil, Greece, Japan, Mexico, New Zealand, Oman, Pakistan, Qatar, Russian Federation, Singapore, South Africa, South Korea, Sweden Switzerland and Tunisia had published one article each. 


\subsection{Analysis by Document}

Table 6. Distribution by Document Type

\begin{tabular}{llc}
\hline Document Type & F & \% \\
\hline Article & 66 & 7.5 \\
\hline Review & 10 & 10.5 \\
\hline Conference papers & 8 & 8.4 \\
\hline Book chapter & 4 & 4.2 \\
\hline Book & 3 & 3.2 \\
\hline Conference Review & 1 & 1.1 \\
\hline Article in Press & 1 & 1.1 \\
\hline Note & 1 & 1.1 \\
\hline Grand Total 8 & 95 & 100 (round)
\end{tabular}

Table 6. This accounts for articles type or document type. This is revealed as seen in most of the research done by a review of articles which gave a frequency of 66 articles, and a percentage of 7.5 of the total articles that were researched. A review of reviewed articles were 10 and with a percentage f 10.5 . Conference papers were 8 , with $8.4 \%$ while book chapters were 4 with $4.2 \%$. There were also 3 books reviewed giving 3.2\%. Also, conference review, articles in the press, notes were 1 each, giving $1.1 \%$ of the articles used for this study

\subsection{Analysis by Subject.}

Table 7. Distribution by Document

\begin{tabular}{ll}
\hline $\begin{array}{l}\text { Subject Area (Course) } \\
\text { \% }\end{array}$ & F \\
Course & 8 \\
\hline Medicine & 4 \\
\hline Psychology & 3 \\
\hline Health Professions & 3 \\
\hline Social Sciences & 3 \\
\hline Engineering & 6 \\
\hline Computer sciences & 5 \\
\hline Neurosciences & 3 \\
\hline Business Mgt \& Account & 2 \\
\hline Agric and Biology Science & 2 \\
\hline Earth Planetary Science & 1 each \\
\hline Arts and Humanities, & 8 \\
\hline Biochemistry, Genetics and Microbiology, Decision Sciences, Material & \\
Sciences, Nursing, & \\
\hline Pharmacology Taxocology, Veterinary and Undefined. & \\
\hline
\end{tabular}

Table 7 show the distribution of the subjects that were studied or researched. The table shows that Medicine had 8 articles published, followed by Computer Sciences with 6 articles while Psychology, with 4 articles published within the period of research. Health professions, 
and Social Sciences, Business management, Engineering had 3 articles each. Agricultural science and biology, Earth and Planetary Sciences had 2 articles, but the rest of the courses had 1 article each and also a different article.

\section{Evaluation of Related Articles Theoretically and Practically \\ Relationship of articles to topic}
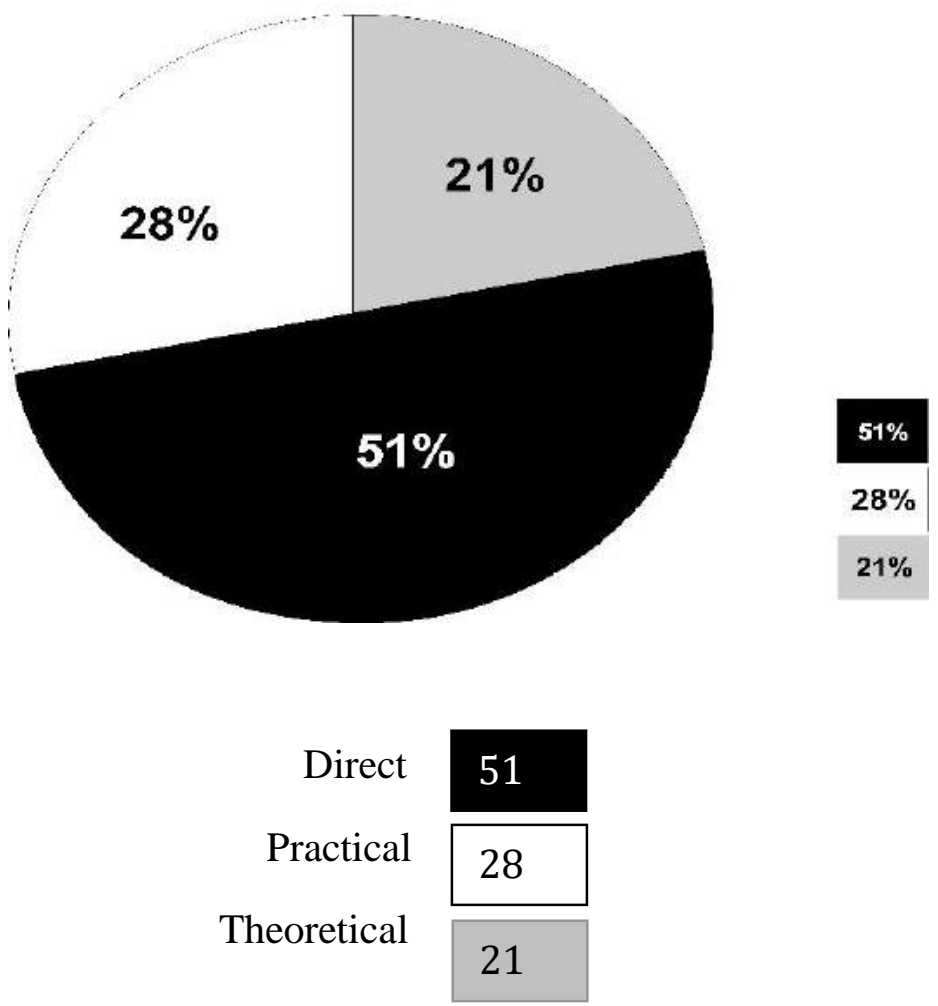

Figure 2. Distribution of Articles Depending on Theory or Practice

The relation of the articles in terms of its theoretical and practical ability to the topic of discussion is seen in the pie chart above (Graph 2). The articles that were directly related to the topic had a frequency of 22 giving $21 \%$ of the total articles that were analyzed. Those articles that were practically related to the topic had a frequency of 54 making $51 \%$, while those that were theoretically related with a frequency of 29 and had $28 \%$ of articles published.

The statistical methods used by the writers in these articles are shown below

Qualitative design........ $77 \quad 81 \%$

Quantitative................17 $18 \%$

Mixed method............1 $1 \%$

\section{Discussion}

This review on content analysis of efficacy of psychological guidance in sports performance in secondary schools had 95 psychological articles and related material were studied between 
1937 and 2017. And additional literature search was used in the sister journals of sports and of psychology in order to come to an agreement of the topic in question from 1960 to 2017. The origin and literature of these journals began this year. The research was conducted through literature review of published articles in the index Scopus database. In other to have a complete overview of all the studied material, ( $\mathrm{n}-95), 13,000$ from sports journals and 5,000 that were examined and a careful application revealed a selection criterion which the researcher ended up with 95 materials for the final review. This reveals a high need in the area of study, although there is a ray of hope.

The analyzed search results obtained the articles by year, source, author, affiliation, country and by course in all the 81 years that were researched in content analysis of psychological guidance in sports performance. During the search, other areas that were involved included, Medicine, Biology, Social Sciences, Pharmacy, Health Education, Biochemistry, Computer Science, Agriculture, Microbiology, and similar areas. A close look at the study from 1937, there were no publications again until 1968 where one article was published. The graph continued in that progression until in the year 2004 when the articles increased to 3 and 4 in 2008 and 2016, but in 2006 and 2014 the articles had risen, so the graph isn't normal with the trend of movement. In the year 2015 the articles were 10 while they increased to 12 in 2017 . It is evident that there is a growing increase in publications and therefore shows that there is enlightenment in this area of study, and therefore should expect more articles subsequently. The graph did not give normal curve from the inception but in the subsequent years 2000 to 2017, the curve became visibly normal.

Viewing the distribution of articles by source, for the 81 years' period, Egitim Arastirmalari Eurasian, Journal of Sports Science, Perception and Motor Skills had written 3 articles each, while Chinese journal of Clinical Rehabilitation, Caudemos de Psicologicia del. D., Pediatrics, and Scandinavian Journal of Medicine had 2 articles each. A little look at the journal on sports, one will see that different sources were able to make some good publications between the years 1960 to 2017. Research Quarterly for Exercise published 128 articles, Plos One100, BMC Public Health 93, Archives of Physical Medicine 53, Journal of Sports Science 57, Perceptual and Motor Skill 56, Social Science and Medicine 56, this continued to the list that had 8 publications, un like the others in psychological guidance and sport that have one article each, which clearly shows the need for more articles in the area of sports, going by the number of articles written in these 81 years. Most writers preferred publishing one article this period this is probably because it was at the onset of World War 2 thereby scaring most of the writer to publish. This can be evident in a look at sports articles published from 1960 to 2017 which shows a great difference in the number of articles published, while in 1937 to 201795 articles were published, but from 1960 to 2017 over 13000 articles were published in sports. It is also evident in the psychology journals which showed on increased year in and out. Like in 2015 and 2016 there were 1145 and 1063 articles that were respectively published in these years. Even though the world war had just ended, but the interest of writers was more on sports and psychology than in psychological guidance in sports.

On the distribution of article according to author, the research shows that Michele, L. J and Theeboom, M. wrote 3 articles each while Luo, O., Vertonghan, J., and Visscher, C. wrote 2 articles in this 81 years' period of search. Most authors had one article each and it goes to show that the area has needs for more research and publications. Except for the 2 authors that had 3 articles in the 81 years of research, none again. While a look at articles on sports, one will see that an author has 48 some 39, another 37, 32, 27, 26, 25 to the list person with 8 published articles in the publication, just within the period of 47 years unlike that of psychological 
guidance. Similarly, a cross look at the journal on psychology and sports, authors were able to publish 14, 11,10,9 journals respectively within this same period (1960).

The research also revealed that Virji University Brussels, published, 3 articles with a $1.55 \%$. Contro de Estudies University, University of Gragningen, Birmingham, Kingston, North Carolina, Washington, Ku Levuven, Huazhong Normal University, Wuhan Sports University, published 2 articles each at a cumulated percentage of 9.23, but a frequency of 195 of the affiliates having 89.23 of the total population published only an article each. This shows the inability of the writers to publish articles within the period under research was probably due to the inadequate number of articles which will led to financial lose as this involves a lot of resources. But as seen in the sister journal, on psychology, the University of Toronto, had 109 articles affiliated to them, University of Sydney 87, VA medicine 86, Harvard Medical School 81, University of North Carolina 79, University of Queensland 77, University of California San Francisco 71, University of Washington and Michigan had 70 each so it continued till the last which was the university of Tehran, Alabama, Harvard, Case Western Reserve Nation Taiwan had 18 each. Also, the distribution of articles by country showed that 23 articles were written by the United States followed by China with 16 articles and the United Kingdom 10. Many other nations had 8, 6, 5, 3, and 2 that were published in the years under review. Despite the dare need of Psychological guidance in sports in secondary schools, only South Africa and Tunisia were the only African nations that were able to publish an article each within the years of study. Meaning that Nigeria does not have enough psychological guidance counsellors or no enough writers or researchers and therefore showing a lack in this area and the African continent. It wasn't long that the United States had returned from war, they still took the lead in article writing. With 3256, there were 1907 Undefined articles but the United Kingdom 1136, China, 794, Australia 784, Germany 653, Canada 593, Spain 591, France 502, Russian Federation 445, Brazil 358, It was similar with articles in the journal of psychology and sports. The United States had 2914 publications, United Kingdom 759, Unidentified 742, Canada 540, Australia 539, Netherlands 288, and Germany 282 within the period 1960 to 2017. They were able to continually publish in view of the number of articles received and they used the income generated for more publications.

In the research, there were revelations that topics which were related, were sorted out into frequency of 95 with a percentage of 100. From the studied samples, 95 all came from index Scopus, among which one was unidentified. The medicine had the highest published articles of 8 , while psychology had 4, Health promotions and Social Sciences had 3 articles each. The much written articles from medicine may be attributed to the clinical therapy mental disorders that might have led to much research within the period. But for their counterparts in sports articles, Medical and science in sports wrote 593 articles Teortya. I Praktika Fizicheskoy K., had 396, Research Quarterly for Exercise had 346, journal of strength and condition with 339, Journal of sports Medicine 251, Journals of sports science 243, British Journal of sports Medicine 215, Sports education and society 202 so it continued to the list which was Advances in Environmental Biology having 12 articles. The number of articles as per the subject area in the psychological journal in sports also showed that Medicine had over 5710 publications, Psychology 1151, Social Sciences 987, Health Professions 867, Biochemistry, Genetics, 454, Arts and Humanities, 311, Neurosciences 292, Agriculture and Biological Sciences 149 most of the others had below hundred but the number was greater than that of psychological guidance and sports performance for 81 years. Though it was after the world war, but one can say that writers preferred sports journals and psychology journals rather than psychological guidance in sports, which then shows that there was little or no knowledge of the subject, therefore didn't write on it. 
Further study reveals that most of the documents that were used for the research were review of articles which gave a frequency of 67 articles and a 7.5\% of articles studied, a review of reviewed articles 10 and $10.5 \%$, conference papers were 8 and $8.4 \%$ while book chapter were 4 giving $4.2 \% .3$ books were also reviewed having $3.2 \%$, conference reviews, articles in the press, notes were one each and had $1.1 \%$. Over 6290 documents were reviewed, in the publication of psychology where 843 were from reviewed articles, 145 conference,59 editorials, 48 notes, 43 book chapter, 39 books 36 short survey, 27 letters, 13 articles in the press Erratum 1 of which

Finally, the methods used by these writers were mostly qualitative and had a frequency of 77 that is $82 \%$, quantitative 17 at $15 \%$ while mixed was 1 article making the balance of $1 \%$ the statistics in the research shows that descriptive and inferential were often used, where it has mean, Median, variance, percentage and the inferential had t- test, chi square, multiple regression.

\section{Conclusion}

Psychological guidance is expected to be a guide and assistance to all learners especially in the educational system, where the needed age grade is found for the delivery of tasks, especially as regards sports, therefore to achieve better sports performance, stable emotional, social, physical health concerns of learners, adequate encouragement, motivation, the dare need for psychological guidance is required in all sports programmers especially in secondary schools. A critical view of the 95 documents by this research reveals that there is a great demand for more publications for the awareness of such a barren area of education. A vivid look at the 95 documents analyzed, from the 81 years of documents searched, all the documents area of study was involved, that is, Medicine, Pharmacy, Social Sciences, Microbiology, Health Education and more. Similarly, sister journals in Sports and Psychology was also done. Encouragingly, in all the three different journals, there was an increase in the number of journals daily or yearly only that it was more in the areas of Sports and Psychology than in the area of Psychological guidance in sports. Popular publishers had the most of the publications example, Egitim Arastirmalari Eurasian journal of sports science, Perception and motor skills. But in the sister journals of sports and psychology, there were more publication in about half of the 81 years seen in psychological guidance and sports. There publications were 128 per journal for that period to the list of publications of 8 in 1960 to 2017.

As authors like Michele, $\mathrm{L}$ and Theeboom, $\mathrm{M}$ made the highest publication of 3 articles each for the duration under study in psychological guidance in sports, its sister journals sports and psychology published 48,39,37 journals for the years 1960 to 2017. Also seen in the publisher's number of articles for these years, Virji University Brussels, had 3, while most of the publishers published 2 articles or less, unlike their sports and psychology counterparts in the University of Toronto, 109, Sydney87, VA Medicine 86 and the like. Among the nation that published, United State had the most with 3256, United Kingdom 1136, while china 794 in the year 1960 to 2017 in the sports journals. In Psychology journal, was able to published 1,145 and 1063 articles in 2015 and 2016 respectively. Though medicine took the lead in article publication in the 81 years of search in psychological guidance in sports, with 8 articles, psychology 4, this was nothing compared to the other contemporary journals (Sports and Psychology), Medicine had the lead in the publications also, with 593, Teortya Praktik Fizicheskoy, had 397 articles in 1960 to 2017, in the sports journal, and as Medicine still lead in the Psychology journal production with 5,710 publications, it was followed by psychology with 1,151, while Social Sciences 987 in the year 1960 to 2017. 
Finally, a lot of evidence has proven that most of the writers preferred to write on single journals Sports or Psychology and not on Psychology and Guidance in Sports performance. For these reason the area is still virgin and unexplored and needs exploration.

\section{References}

Bucher, C. A. (1972). Foundations of Physical Education... With 287 Illustrations. CV Mosby Company.

Britannica, E. (2009). Encyclopædia britannica. Chicago: Common Law.

Burt, R. S., Jannotta, J. E., \& Mahoney, J. T. (1998). Personality correlates of structural holes. Social Networks, 20(1), 63-87

Jaiyeoba, A. O., \& Ademola, A. I. (2014). Re-Engineering Tertiary Education (University) For Sustainable Development in Nigeria.

Long, J., \& Sanderson, I. (2001). 12 The social benefits of sport. Sport in the city: The role of sport in economic and social regeneration, 187.

Rimm, S. B. (2008). Why bright kids get poor grades and what you can do about it: A six-step program for parents and teachers. Great Potential Press, Inc.

Wallhead, T., \& O'sullivan, M. (2005). Sport education: Physical education for the new millennium? Physical Education and Sport Pedagogy, 10(2), 181-210.

\section{Biodata of the Corresponding Author}

Associate Professor Doctor Engin BAYSEN was born in Cyprus in 1971. After graduated from elementary and secondary school in Cyprus, he started his university education in 1989 in Ankara Gazi Education Faculty Department of Physics Education and graduated as a Physics and Science teacher. He got his Master and PhD from Ankara Gazi Institude of Sciences Department of Physics Education and Ankara Gazi Institude of Social Sciences Department of Physics Education respectively. He worked as a Science and Physics teacher in numerous primary and secondary schools of Turkey during 1998-2007. After being assigned as an Assistant professor to Kirsehir Ahi Evran University Education Faculty in 2007, and worked for a short time, he started working in Near East University Ataturk Education Faculty in year 2007 and he is still working in Near East University Nicosia Cyprus now. 


\title{
THE ROLE OF PHYSICAL EDUCATION FOR CHILDREN WITH SPECIAL NEEDS: A REVIEW STUDY
}

\author{
Basak Baglama ${ }^{1}$, Mukaddes Sakalli Demirok ${ }^{2, *}$ \\ ${ }^{1}$ Department of Special Education, Atatürk Education Faculty, Near East University, North Cyprus, Mersin 10 \\ Turkey, basak.baglama@ neu.edu.tr \\ ${ }^{2}$ Department of Special Education, Atatürk Education Faculty, Near East University, North Cyprus, Mersin 10 \\ Turkey, mukaddes.sakalli@neu.edu.tr \\ Correspondence: mukaddes.sakalli@ neu.edu.tr ; Tel.: +90 (392) 2236464
}

\begin{abstract}
Sports and physical activities improve individuals' physical, physiological and psychological health and regulate social behaviors from biological, pedagogical and social dimensions. Sports practices for individuals with special needs have a great importance in their daily life activities and quality of lives. This study aims to this study aims to provide a scientific and systematic review for the benefits and outcomes of physical education and sports in special education. A comphrehensive and systematic literature review was carried out in order to achieve this aim. "No disability in sports" and "importance of physical education and sports for individuals with special needs" were discussed with relavant literature and recommendations for further research and practives were presented.
\end{abstract}

Keywords: physical education, sports, individuals with special needs

\section{Introduction}

The first practice of physical education as a course for children with special needs was carried out in United States. Essentiality of physical education in special education was regarded as an important issue and today physical education is accepted as an important part of special education practices (Adapted Physical Education National Standards, 2008; Buchanan, Miedema \& Frey, 2017). Adapted physical education is physical education which has been adapted for individuals with special needs. Various rules, regulations and legislations necessitate the integration of physical education into special education and it is emphasized that physical education provided to students with special needs need to support and improve many skills and domains as shown in Figure 1. As it can be seen in Figure 1, these skills and domains include physical and motor skills, dance, individual and group games and aquatics.

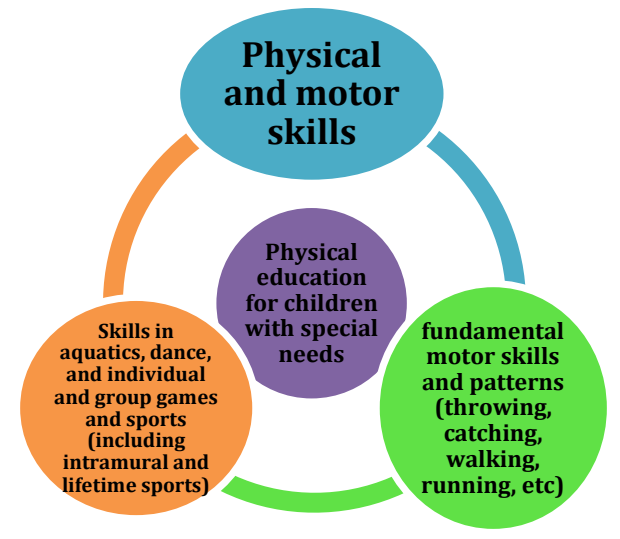

Figure 1. Skills and Domains Supported by Physical Education for Children with Special Needs 
Since physical education is an essential component and part of special education, physical education teachers are expected to provide services in order to meet the requirements of children with special needs. These services involve planning, assessment, prescription/placement, individualized education programs preparation process, teaching, counseling, coaching, evaluation, coordination of resources and consulting and advocacy (Sherrill, 1998). When physical education and sports practices for individuals with disabilities are considered, it is aimed to contribute them in terms of being a self-sufficient person, maintaining their lives independently in the society and increase their social adaptations. Physical education programs for children with special needs need to be prepared based on their requirements and individual characteristics such as diagnosis, severity of diagnosis and existing performance level (Hutzler, 2003; Block, 2007; Ozer \& Sahin, 2010).

Essentiality of physical education programs were mentioned in the past in the academic literature. For instance, Gallahue (1987) mentioned that in the first stage, children with special needs require adapted physical education programs, in the second stage, they need rehabilitative physical education programs and they need constructive physical education programs in the last stage. It is known that physical activities helps children with special needs to develop self-concept and social competence, develop motor skills, physical and motor adaptation, leisure time skills, playing and creative time skills as long-term objectives. Physical activities for children with special needs are required to be competent in terms of improving psychomotor, sensory and cognitive development. If these developmental domains are achieved, these long-terms objectives will be achieved as well. Nevertheless, physical group activities promote sharing, communication and learning social behaviors among individuals with special needs (Konar \& Yildiran, 2012; Ozer \& Sungu, 2016).

Psychomotor domain plays an important role in social and emotional development of individuals with special needs and physical education and sports support them to acquire motor skills in the following ways. Therefore, individuals with special needs could be able to fulfill fine and gross motor skills easily.

- Enhacing the development of basic components of body structure,

- Participating in physical activities and development of physical and motor appropriateness levels,

- Gaining coordination,

- Constituting muscle endurance and strength, body balance and flexibility,

- Reinforcement of perceptional motor functions, kinesthetic and tactile perception (Pahor, Guralnik, Ambrosius, Blair, Bonds, Church \& King, 2014; Koh, 2016).

In addition to psychomotor skills, individuals with special needs also gain basic objectives regarding sensory domain. These objectives are as follows:

- Coping with life problems and positive perception of self-esteem,

- Adaptation to the environment,

- Learning and achieving self-realization (Armour, 2014; Shields \& Synnot, 2016).

Given the importance of physical education and sports activities in the lives of individuals with special needs, this study aims to provide a scientific and systematic review for the benefits and outcomes of physical education and sports in special education in a comprehensive manner. 


\section{Method}

In order to achieve the aim of the study, different international academic databases were searched and publications regarding physical education for individuals with special needs were included and examined in the study. The literature search was carried out with keywords involving "physical education", "sports" "special education" and "disability".

\section{Results and Discussion}

\subsection{No Disability in Sports}

Physical education, recreation, and sports activities primarily have the purpose of helping individuals with special needs to be happy and self-sufficient person, have life motivational and social adaptation. It is aimed to acquire sports habits and a society with individuals with special needs making sports (Kinali, 2003; Auxter, Pyfer \& Huettig, 2005). Sports bring all people together and therefore contributes to social integration and participation of individuals with special needs. In other words, sports do not recognize any disability (Hodge \& Jansma, 1999). When examined, it is seen that handicapped players show many important achievements in Paralympic games (Taskin, 2014). Especially, players with physical, visual and hearing disabilities have important gains in many sport branches.

In this context, physical education, game and sports activities for individuals with special needs requires important competence (Barton, 2017). Accordingly, European countries established educational institutions in order to train professional groups who can meet these requirements. For example, Germany Koln Sports Academy (Sporthochschule) Department of Sports and Rehabilitation train physical education teachers specialized for teaching individuals with special needs. It is also emphasized that physical education and activity needs of individuals with special needs must be carried out based on collaboration family, physical education teacher, physiotherapist and special education professionals.

The scope of sports concept comprises all different gender, age, performance groups, disease, type and severity of disability and social and economic conditions. Dimension of sports in the society necessitates physical education and sports activities for individuals with special needs as well. Increasing quality of lives and achieving integration and rehabilitation of individuals with special needs requires providing specific sportive conditions and opportunities for every disability group and human power who has this knowledge and skills are needed as well. Understanding of "No Disability in Sports" has become more prevalent in the recent years and more participation of individuals with special needs would increase their social integration and life adaptation (Bloemen, Backx, Takken, Wittink, Benner, Mollema \& De Groot, 2015).

\subsection{Importance of Physical Education and Sports for Individuals with Special Needs}

It is widely known that physical education and sports play a crucial role in the lives of individuals with special needs having different type and severity of disabilities. According to Ergun (2003), sports make individuals with special needs to improve their physical and emotional structure, discipline, competition, friendship and social roles. Universal language of these social roles is physical education and sports. Sports develop understanding, carrying responsibilities and collaboration and increase social cohesion in the group.

Physical education and sports activities also help individuals with special needs to control aggressive and impulsive behaviors (Morris \& Schulz, 1989). Since sports leads individuals to participate in social environments as a social activity, it has an important role in socialization 
of individuals as well. In modern societies, sports is considered as a collective activity and people establish social relationships through sportive activities. From this perspective, it can be indicated that individuals with special needs can communicate with others and participate into the society (Yetim, 2005).

Taliaferro, Hammond and Wyant (2015) found that physical education and sports practices carried out in the university campus increased the self-efficacy levels of preservice teachers about inclusion of individuals with special needs. According to the literature, it is emphasized that preservice teachers who received physical education and sports for individuals with special needs have more positive attitudes and expectations towards individuals with special needs. In addition, providing environments for students beginning from early childhood to higher education in which students will increase their knowledge, acceptance and interaction with individuals with special needs is really important.

\section{Conclusion and Recommendations}

It is really important in special education to increase quality of life, participation in daily life activities, socialize and prepare programs based on individual characteristics plays a great role in the lives of individuals with special needs. Therefore, individuals with special needs would be able to cope with obstacles, communicate, socialize, have fun and higher levels of motivation and develop positive personality characteristics. Physical education and sports are important parts of individuals with special needs and therefore more studies need to be carried out in this field in order to improve educational policies and practices. The present study aimed to provide a systematic and comprehensive literature review in order to reveal the importance of physical education and sports activities for individuals with special needs through content analysis. In conclusion, the results of the study showed that physical education and sports activites play an important role in the lives of individuals with special needs and these practices need to be provided by qualified professionals. In line with these results, the following recommendations for further research and practices are provided as well:

- Physical and motor developments of individuals with special needs should be periodically monitored.

- There should be a physical education teacher who is competent in teaching individuals with special needs in every special education and rehabilitation institution and/or inclusive education.

- Open and closed environments should be organized for physical education of individuals with special needs.

- Essential materials for movement, coordination and other physical education practices should be supplied in every special education and rehabilitation institution and/or inclusive education.

- According to the evaluations and observations, duration of physical education of individuals with special needs might be increased and developmental level could be followed.

- Inservice trainings for special education professionals and physical education teachers might be organized in order to increase their knowledge, skills and competencies about the importance of physical education, current trends and applications in physical education for individuals with special needs and how to integrate physical education into special education practices.

- There should be more courses related with physical education during special education teacher training programs at the universities. 
- Families of children with special needs should become more aware about the necessity of physical education for their children.

\section{References}

Adapted Physical Education National Standards, (2008). APENS 15 standards of specialized knowledge. Retrieved from: https://www.apens.org/15standards.html

Armour, K. (Ed.). (2014). Pedagogical cases in physical education and youth sport. US: Routledge

Auxter, D., Pyfer, J. \& Huettig, C. (2005). Principles and methods of adapted physical education and recreation. Dubuque, IA: McGraw-Hill

Barton, L. (2017). Disability, empowerment and physical education. In Equality, education, and physical education (pp. 43-54). US: Routledge

Block, M. E. (2007). A teacher's guide to including students with disabilities in general physical education. UK: Brookes Publishing Company

Bloemen, M. A., Backx, F. J., Takken, T., Wittink, H., Benner, J., Mollema, J., \& De Groot, J. F. (2015). Factors associated with physical activity in children and adolescents with a physical disability: A systematic review. Developmental Medicine \& Child Neurology, 57(2), 137-148

Buchanan, A. M., Miedema, B., \& Frey, G. C. (2017). Parents' perspectives of physical activity in their adult children with autism spectrum disorder: A social-ecological approach. Adapted Physical Activity Quarterly, 34(4), 401-420

Ergun, N. (2003) Bedensel engelli cocuk ve spor. Coluk Cocuk Dergisi, 5(26), 50-55

Gallahue, D. L. (1987). Developmental physical education for today's elementary school children: instructor's resource manual with transparency masters. US: Macmillan

Hodge, S. R., \& Jansma, P. (1999). Effects of contact time and location of practicum experiences on attitudes of physical education majors. Adapted Physical Activity Quarterly, 16, 48-63

Hutzler, Y. (2003). Attitudes toward the participation of individuals with disabilities in physical activity: A review. Quest, 55(4), 347-373

Kinali, G. (2003). Zihin engellilerde beden-resim-muzik egitimi. Istanbul: Epsilon Yayinlari

Koh, Y. (2016). Systematical review: Why it needs to provide adapted physical education courses and practicum to teach students with intellectual disability in general physical education. Asia-Pacific Journal of Intellectual Disabilities (APJID), 3(2), 37-47

Konar, N., \& Yildiran, I. (2012). Engelliler icin beden egitimi ve spor ogretmenligi: Gereksinim ve bir program modeli. Selcuk Universitesi Beden Egitimi ve Spor Bilim Dergisi, 14(2), 208-216

Morris, L. R., \& Schulz, L. (1989). Creative play activities for children with disabilities: a resource book for teachers and parents. US: Champaign, IL 61825-5076

Ozer, D. S. (2001). Engelliler icin beden egitimi ve spor. Ankara: Nobel Publishing

Ozer, D., \& Sahin, G. (2010). Engelli bireyler icin fiziksel aktivite: 2009-2010 calistaylari sonuc raporu. Gazi Beden Egitimi ve Spor Bilimleri Dergisi, 15(2), 21-28 
Ozer, D., \& Sungu, B. (2016). Beden egitimi ogretmen adaylarinin bakis acisindan "engelliler icin beden egitimi ve spor dersi” uygulamalari. Spor Bilimleri Dergisi, 27(1), 1-15

Sherrill, C. (1998). Adapted physical activity, recreation and sport: Crossdisciplinary and lifespan. US: McGraw Hill

Shields, N., \& Synnot, A. (2016). Perceived barriers and facilitators to participation in physical activity for children with disability: A qualitative study. BMC Pediatrics, 16(1), 1-10

Taliaferro, A. R., Hammond, L., \& Wyant, K. (2015). Preservice physical educators' selfefficacy beliefs toward inclusion: The impact of coursework and practicum. Adapted Physical Activity Quarterly, 32(1), 49-67

Taskin, R. (2014). No Obstructions in Sports. II. International Conference on Physical Education and Sports in Disabilities Book of Abstracts, p. 43-45, Batman, May 2-4, 2014

Yetim, A. (2005). Sosyoloji ve spor. Trabzon: Topkar Matbaacilik

\section{Biodata of the Corresponding Author}

Sakalli Demirok, Mukaddes, Associate Professor, Near East University, and head of the department of special education. She is an author, researcher and lecturer whose interest include special education, giftedness, hearing impairments, down syndrome, autism and scientific study of education. 


\title{
A COMPARATIVE ANALYSIS OF SCHOOL DIRECTORS' DIGITAL CITIZENSHIP IN TURKMENISTAN AND TRNC (Turkish Republic of North Cyprus)
}

\author{
Gulnoza Ibragimova ${ }^{1}$, Umut Akcil 2," \\ ${ }^{1}$ Department of Computer Education and Educational Technology, Ataturk Education Faculty, Near East \\ University, North Cyprus, Via Mersin 10, Turkey \\ ${ }^{2}$ Department of Computer Education and Educational Technology, Ataturk Education Faculty, Near East \\ University, North Cyprus, Via Mersin 10, Turkey, uakcil@gmail.com \\ Correspondence: uakcil@gmail.com ; Tel.: +90 (392) 2236464
}

\begin{abstract}
This research aimed to determine the level of digital citizenship of the school directors in Turkmenistan, a developing country, and compare the level of digital citizenship of the school directors of the Ministry of National Education in TRNC. A causative comparison, one of quantitative designs, was conducted in this research. The participants were secondary school directors of the Ministry of National Education, TRNC in the 2017-2018 academic year. Convenience sampling method was used in this study. Due to time constraints and because it was easier, only 45 high school directors in Lefkosa, TRNC were involved. In Turkmenistan, 38 high school directors in the city of Dasoguz could be reached. The total number of the participants was 83 . The "digital citizenship scale" and personal information form were used in this research. When the rate of Digital Citizenship, based on countries, is examined, the level of digital citizenship of the Turkish (TRNC) secondary education school directors is observed to be higher than of the Turkmeni secondary education school directors.
\end{abstract}

Keywords: digital citizenship, school directors, education management, developing country

\section{Introduction}

Today, digital technology has become an essential part of our life in almost every field such as; technology, social, economical, political, and educational. The use of technology plays an important role in our life. At the same time, it is a causative factor in changing people's lifestyles. From the past up today, technology is an effective tool in every field. Undoubtedly, education is one of the fields affected by technology intensively.

While facilitating people's daily lives, technology plays a great role in education and educational activities making the processes fast, practical, and reliable. Not only students, but teachers, even educational managers also should be involved in the rapidly changing educational systems (Aydin, 2015). The means in which informatics and technology are used, have become widespread in due course and thus every individual can easily communicate. As a result of all these developments, the "Digital Citizenship" concept has emerged.

The impact of the internet on individuals and communities has carried the concept of "digital citizenship" to a digital frame and as a result, the "digital citizenship" concept has emerged (Aydin, 2015). People who have adapted themselves to the digital world, can share their ideas and feelings freely, and can meet their daily needs (banking, shopping etc) on the internet. It can be observed that from State to private sectors all managers have integrated in the digital 
world, because managerial issues can be dealt with faster through the internet. These facilities have made communities dependent on the internet and they have been considered as "digital citizens" (Mossberger, 2008).

Literature presents several studies done in the concept of "Good Digital Citizenship". Kılınç and Dere (2013) argue that the main aim of all political systems is to raise the new generation as" good citizens". Safran (2008) adds that educational systems have the most crucial responsibilities for the achievement of this aim. In such a process, educational managers should take the lead as they are in the top positions. "Digital Citizens" are the ones who use technology and technological tools properly, who are respective to individual rights and rules as well as ethical rules and most important of all the ones who are aware of the responsibilities for and safely use of these tools (Mossberger, Tolbert \& McNeal, 2007).

In this information age, educationalists, who are considered as the most important actors in education systems, should inevitably adapt themselves to technological changes. "The International Society for Technology in Education" (ISTE) has set some educational standards, which draw attention to the importance of being digital literates, interacting technology in teaching, guiding students to the use of technology, helping them develop skills in reaching information and using it, and sharing professional experiences with colleagues in using the internet collaboratively (ISTE, 2000). These standards are also the requirements for digital citizenship.

Particularly school directors and all the educationalists should effectively use the digital platform and participate in education to do with digital citizenship. This will naturally reflect to their attitudes and behaviors in digital environments. In the broader sense, the basic aim of educational systems is to raise qualified generations and help students to become good literates of technology. At this point, teachers and school directors have the biggest responsibilities. Every school director whose staff and students use the digital platform effectively is a good digital citizen. They assume digital citizenship an alternative approach so as to integrate technology in the lives of new generations (Alberta, 2012).

With this in mind, this research aimed to raise the level of digital citizenship of the school directors in Turkmenistan, a developing country, and compare the level of digital citizenship of the school directors of the Ministry of National Education in TRNC. Answers to the subaims were seeked through the following questions;

1. What are the levels of digital citizenship of the school directors in Turkmenistan and TRNC?

a) At what level, in terms of sub-dimensions, is the distribution of digital citizenship behaviors of school directors in Turkmenistan and TRNC?

2. Is there a significant difference between the school directors in Turkmenistan and TRNC in terms of the level of their digital citizenship?

a) Is there a difference between the school directors in Turkmenistan and TRNC in terms of the sub-dimensions of digital citizenship?

\section{Methodology}

This research aimed at comparing school directors' digital citizenship behaviors in schools in Turkmenistan and in TRNC. A causative comparison, one of quantitative designs, was 
conducted in this research. Causative comparison methods examine the cause-effect results among variable differences (Buyukozturk, 2007).

The participants were secondary school directors of the Ministry of National Education, TRNC in the 2017-2018 academic year. Due to time constraints and because it was easier, only 45 high school directors in Lefkosa, TRNC were involved. In Turkmenistan, 38 high school directors in the city of Dasoguz could be reached. The total number of the participants was 83. A convenience sampling method, one of random sampling methods, was used in this research. Due to time, money, and workforce constraints, this method is preferred because it is easier to reach the samplings and the procedure is applicable (Buyukozturk, Çakmak, Aygun, Karadeniz \& Demirel, 2017).

A Digital Citizenship Scale and a Personal Information Form were used to collect data. The Scale, developed by Akcil (2015), consists of 10 sub-dimensions, with 39 items. The reliability coefficiency (Cronbach's Alpha) calculated by the researcher, was found as 0.87 . The subdimensions of the Scale, developed by Akcil (2015) were specified as digital literacy, digital rights and responsibilities, digital commumication, digital security, digital trade, digital access, digital ethics, digital health, the use of digital tools and digital storage. The scale is a 5-likert type and the sequencing of resposes are as, "I always agree" (5), "I mostly agree" (4), "I partly agree" (3), "I don't agree" (2), and "I disagree" (1). The reliability coefficiency of this study was calculated as 0.94 .

\section{Findings and Discussions}

\subsection{The Demographic Distribution of the Participants is as in Table 1}

Table 1. Demographic Information about the Participants

\begin{tabular}{llcccc}
\hline & & \multicolumn{2}{c}{ Turkmenistan } & \multicolumn{2}{c}{ TRNC } \\
& & f & \% & f & \% \\
\hline & $26-36$ & 16 & 42.1 & 0 & 0 \\
\hline Age & $32-37$ & 8 & 21,1 & 2 & 4,4 \\
\hline $37-43$ & 2 & 5,3 & 2 & 4,4 \\
\hline & $44-49$ & 6 & 15,8 & 13 & 28,9 \\
\hline Task type & Total & 6 & 15,8 & 28 & 62,2 \\
\hline & Director & 38 & 100,0 & 45 & 100,0 \\
\hline Assistant & 15 & 39,5 & 8 & 17,8 \\
\hline director & Total & 23 & 60,5 & 37 & 82,2 \\
\hline PC usage year & 0-7 Year & 38 & 100,0 & 45 & 100,0 \\
\hline & $8-15$ Year & 10 & 26,3 & 3 & 6,7 \\
\hline & 16 and over & 21 & 55,3 & 19 & 42,2 \\
\hline & Total & 7 & 18,4 & 23 & 51,1 \\
\hline & Less than 1 hour & 2 & 5,3 & 7 & 15,6 \\
\hline & $1-3 h o u r$ & 24 & 63,2 & 20 & 44,4 \\
\hline
\end{tabular}




\begin{tabular}{|c|c|c|c|c|c|}
\hline PC usage duration & 4-6 hour & 8 & 21,1 & 13 & 28,9 \\
\hline & 7-9 hour & 4 & 10,5 & 5 & 11,1 \\
\hline & Total & 38 & 100,0 & 45 & 100,0 \\
\hline & 0-7Year & 21 & 55,3 & 7 & 15,6 \\
\hline & 8-15 Year & 15 & 39,5 & 25 & 55,6 \\
\hline \multirow[t]{3}{*}{ Internet usage year } & 16 and over & 2 & 5,3 & 13 & 28,9 \\
\hline & Total & 38 & 100,0 & 45 & 100,0 \\
\hline & Less than 1 hour & 11 & 28,9 & 11 & 24,4 \\
\hline \multirow[t]{6}{*}{ Internet usage duration } & 1-3hour & 19 & 50,0 & 22 & 48,9 \\
\hline & 4-6 hour & 8 & 21,1 & 7 & 15,6 \\
\hline & 7-9 hour & 0 & 0 & 5 & 11,1 \\
\hline & Total & 38 & 100,0 & 45 & 100,0 \\
\hline & Smart Phone & 3 & 7,9 & 6 & 13,3 \\
\hline & Laptop & 16 & 42,1 & 8 & 17,8 \\
\hline \multirow[t]{4}{*}{ Device } & Mobile \& Laptop & 12 & 31,6 & 15 & 33,3 \\
\hline & Mobile \& Taplet & 7 & 18,4 & 0 & 0 \\
\hline & All of them & 0 & 0 & 16 & 35,6 \\
\hline & Total & 38 & 100,0 & 144 & 100,0 \\
\hline \multirow[t]{5}{*}{$\begin{array}{l}\text { Smart device usage } \\
\text { duration }\end{array}$} & Less than 1 hour & 11 & 28,9 & 20 & 44,4 \\
\hline & 1-3hour & 25 & 65,8 & 16 & 35,6 \\
\hline & 4-6 hour & 2 & 5,3 & 6 & 13,3 \\
\hline & 7-9 hour & 0 & 0 & 3 & 6,7 \\
\hline & Total & 38 & 100,0 & 45 & 100,0 \\
\hline
\end{tabular}

\subsection{Digital Citizenship Levels of School Directors in Turkmenistan and TRNC}

Table 2. Digital Citizenship Average Scores of Managers in Some Countries

\begin{tabular}{lccccc}
\hline & $\mathbf{N}$ & $\overline{\mathbf{X}}$ & $\mathbf{S S}$ & $\begin{array}{c}\text { Min } \\
\text { Point }\end{array}$ & $\begin{array}{c}\text { Max } \\
\text { Point }\end{array}$ \\
\hline Turkmenistan & 38 & 128.02 & 16.99 & 89.00 & 176.00 \\
\hline TRNC & 45 & 142.35 & 28.48 & 67.00 & 192.00 \\
\hline
\end{tabular}

When the rate of digital citizenship is examined on country bases, school directors in TRNC have a higher level $(\overline{\mathrm{X}}=142.35)$ than of school directors in Turkmeni. Kemp (2016) studied the number of internet users in Turkic Republics and found out that the lowest rate of users (\%12) were in Turkmenistan in terms of population. 


\subsection{An Examination of Sub-Dimension Levels of Digital Citizenship of School Directors in Turkmenistan and TRNC}

Table 3. The Distribution of Average Scores in Digital Citizenship Sub-Dimensions by School Directors in Terms of Countries

\begin{tabular}{lccccc}
\hline $\begin{array}{l}\text { Digital citizenship sub- } \\
\text { dimensions }\end{array}$ & $\mathbf{N}$ & $\overline{\mathbf{X}}$ & $\mathbf{S S}$ & $\begin{array}{c}\text { Min } \\
\text { Point }\end{array}$ & $\begin{array}{c}\text { Max } \\
\text { Point }\end{array}$ \\
& & & & & \\
\hline Literacy & 38 & 17,18 & 3,178 & 12,00 & 25,00 \\
\hline Rights and responsibilities & 38 & 28,60 & 6,096 & 16,00 & 40,00 \\
\hline Contact & 38 & 9,84 & 2,212 & 4,00 & 15,00 \\
\hline Security & 38 & 8,63 & 2,603 & 3,00 & 15,00 \\
\hline Trade & 38 & 7,73 & 3,151 &, 00 & 14,00 \\
\hline Access & 38 & 10,92 & 2,173 & 6,00 & 15,00 \\
\hline Ethic & 38 & 14,42 & 2,872 & 4,00 & 20,00 \\
\hline Health & 38 & 10,71 & 1,575 & 7,00 & 15,00 \\
\hline Portable device use & 38 & 15,78 & 2,682 & 11,00 & 20,00 \\
\hline Use of storage areas & 38 & 11,28 & 5,119 &, 00 & 20,00 \\
\hline Literacy & 45 & 18,80 & 4,418 & 9,00 & 25,00 \\
\hline Rights and responsibilities & 45 & 31,20 & 7,168 & 13,00 & 40,00 \\
\hline Contact & 45 & 11,73 & 3,143 & 4,00 & 15,00 \\
\hline Security & 45 & 11,35 & 3,038 & 3,00 & 15,00 \\
\hline Trade & 45 & 12,37 & 4,080 & 4,00 & 20,00 \\
\hline Access & 45 & 11,08 & 2,626 & 6,00 & 15,00 \\
\hline Ethic & 45 & 15,64 & 3,234 & 5,00 & 20,00 \\
\hline Health & 45 & 10,84 & 2,836 & 3,00 & 15,00 \\
\hline Portable device use & 45 & 16,02 & 3,427 & 7,00 & 20,00 \\
\hline Use of storage areas & 45 & 12,75 & 4,508 &, 00 & 20,00 \\
\hline
\end{tabular}

As it can be observed in Table 3, the examination of the average scores in digital trade subdimensions, it can be noted that Turkmen school directors have the lowest average scores $(\overline{\mathrm{X}}=7.73)$, whereas the lowest average scores in the sub-dimensions of digital security by school directors in TRNC is $(\overline{\mathrm{X}}=11.35)$. As for the digital rights and responsibilities sub-dimension average scores, it can be observed that both the Turkmen $(\overline{\mathrm{X}}=28.60)$ and Turkish (TRNC) $(\overline{\mathrm{X}}=31.20)$ school directors have the highest level. In a study with Social Sciences Teachers in Digital Citizenship, Aslan (2016) found out that almost all the participants were very well aware of digital rights and responsibilities. However, at times, they seemed to be ignoring moral rights unintentionally. In previous studies, it was found out that internet was strictly censured in Asian countries disunited from the SSSR. The most strict limitations are observed in Turkmenistan and Ozbekistan, the north bordering countries of Iran. Kose and Ozen (2011) specified that access to Facebook, Twitter, and Youtube is strictly prohibited in Turkmenistan. 


\subsection{A Comparative Examination of the Sub-Dimensions of Digital Citizenship Levels of School Directors in Turkmenistan and TRNC}

Table 4. A Comparative T-Test Analysis of Digital Literacy Levels

\begin{tabular}{ccccccccc}
\hline & Countries & $\mathbf{N}$ & $\overline{\mathbf{X}}$ & SS & $\mathbf{t}$ & df & $\mathbf{p}$ & Explanation \\
\hline & Turkmenistan & 38 & 17.18 & 3.17 & & & & \\
\hline Digital literacy & & & & & 5.372 & 81 & .057 & $\mathrm{p}>.05$ \\
\hline & TRNC & 45 & 18.80 & 4.41 & & & & \\
\hline
\end{tabular}

As it can be observed in Table 4, a significant difference was not observed between the digital literacy levels of the school directors in Turkmenistan and TRNC ( $p=.057, p>.05)$. Although not much, the digital literacy level $(\overline{\mathrm{X}}=18.80)$ of the school directors in TRNC is higher compared to Turkmeni school directors. When the correlation in the use of ICT in school administration processes, in terms of Digital Citizenship, is overviewed, a positive and meaningful relationship is noted in all dimensions (Canturk, 2016). Therefore, more practice in the use of ICT in administrative issues in any dimension will add to its use in other issues.

Table 5. A Comparative T-Test Analysis of the Levels of Digital Rights and Responsibilities

\begin{tabular}{ccccccccc}
\hline & Countries & N & $\overline{\mathbf{X}}$ & SS & $\mathbf{t}$ & $\mathbf{d f}$ & $\mathbf{p}$ & Explanation \\
\hline & Turkmenistan & 38 & 28.60 & 6.09 & & & & \\
\hline $\begin{array}{l}\text { Digital rights } \\
\text { and } \\
\text { responsibilities }\end{array}$ & & & & & & & & \\
\hline & & & & 1.615 & 81 & .078 & $\mathrm{p}>.05$ \\
\hline
\end{tabular}

Table 5 reveals that, a significant meaningful difference is not noted between the levels of digital rights and responsibilities of school directors in Turkmenistan and TRNC ( $p=.078$, $\mathrm{p}>.05)$. Their average shows that school directors in TRNC $(\overline{\mathrm{X}}=31.20)$ are more committed to their digital rights and responsibilities compared to Turkmeni school directors. Akcil (2015) found out that school directors in TRNC exhibited digital citizenship behaviors at a rate of $\% 73.25$.

Table 6. A Comparative T-Test Analysis of the Levels of Digital Communication

\begin{tabular}{lllllllll}
\hline & Countries & $\mathbf{N}$ & $\overline{\mathbf{X}}$ & $\mathbf{S S}$ & $\mathbf{t}$ & $\mathbf{d f}$ & $\mathbf{p}$ & Explanation \\
\hline & Turkmenistan & 38 & 9.84 & 2.21 & & & & \\
\hline $\begin{array}{l}\text { Digital } \\
\text { communication }\end{array}$ & & & & & 6.740 & 81 & .002 & $\mathrm{p}<.05$ \\
\hline & TRNC & 45 & 11.73 & 3.14 & & & & \\
\hline
\end{tabular}

As it can be observed in Table 6, there is a significant difference in digital communication levels of Turkmenistan and Turkish (TRNC) school directors $(\mathrm{p}=.002, \mathrm{p}>.05)$. The difference points at a higher level in the average score in the sub-dimensions of digital communication of Turkish (TRNC) school directors $(\overline{\mathrm{X}}=11.73)$ compared to Turkmenistan school directors. This finding reveals that Turkmenistan school directors have a low-level of technology use in communication. In their study, Kelly et al. (2015), specified big rates of differences in the use of the social media among Turkic Republics. The number of social media users in these 
Republics, particularly in Turkmenistan, is at a very low level. This can be related to the limitation by the governments in such countries.

Table 7. A Comparative T-Test Analysis of the Levels of Digital Security

\begin{tabular}{lllllllll}
\hline & Countries & N & $\overline{\mathbf{X}}$ & SS & $\mathbf{t}$ & df & $\mathbf{p}$ & Explanation \\
\hline & Turkmenistan & 38 & 6.63 & 2.60 & & & & \\
\hline $\begin{array}{l}\text { Digital } \\
\text { security }\end{array}$ & & & & & 1.889 & 81 & .000 & $\mathrm{p}<.05$ \\
\hline & TRNC & 45 & 11.35 & 3.03 & & & & \\
\hline
\end{tabular}

Table 7 reveals a significant difference in the levels of digital security between Tukmeni and Turkish (TRNC) school directors $(\mathrm{p}=.000, \mathrm{p}<.05)$. This result shows that the average scores in the sub-dimensions of digital security by the Turkish (TRN) school directors are higher compared to Turkmeni school directors. This can be assumed as a failure in practicising digital security by the Turkmeni directors. On the other hand, as it is revealed in Table 2, the lowest average score in digital security in terms of digital citizenship, by the Turkish (TRNC) school directors is $(\overline{\mathrm{X}}=11.35)$. Akcil (2015), in a study, pointed out that school directors did not practise digital security behaviors as expected, in terms of digital citizenship.

Table 8. A Comparative T-Test Analysis of the Levels of Digital Trade

\begin{tabular}{cllllllll}
\hline & Countries & N & $\overline{\mathbf{X}}$ & SS & t & df & $\mathbf{p}$ & Explanation \\
\hline & Turkmenistan & 38 & 7.73 & 3.15 & & & & \\
\hline Digital trade & & & & & 4.795 & 81 & .000 & $\mathrm{p}<.05$ \\
\hline & TRNC & 45 & 12.37 & 4.08 & & & & \\
\hline
\end{tabular}

Table 8 does not reflect a significant difference in the digital trade levels of Turkmeni and Turkish school directors $(\mathrm{p}=.000, \mathrm{p}<.05)$. When the difference is overviewed, the average score of Turkish school directors in the sub-dimensions of digital trade are noted as $(\overline{\mathrm{X}}=12.37)$, which is higher than the score by Turkmeni school directors. This result indicates that the Turkmeni directors' inclination in using digital trade is at a low level compared to Turkish school directors. According to Kose and Ozen (2011), some States, Official institutions, private sectors or educational institutions have either limited or banned access to internet for several reasons. Prohibitions, particularly by States are at serious dimensions, which means banning access to several websites under the control of the States.

Table 9. A Comparative T-Test Analysis of the Levels of Digital Access

\begin{tabular}{lccccccccc}
\hline & Countries & $\mathbf{N}$ & $\overline{\mathbf{X}}$ & $\mathbf{S S}$ & $\mathbf{t}$ & $\mathbf{d f}$ & $\mathbf{p}$ & Explanation \\
& Turkmenistan & 38 & 10.92 & 2.17 \\
\hline Digital Access & & & & & 1.544 & 81 & .751 & $\mathrm{p}>.05$ \\
\hline & TRNC & 45 & 11.08 & 2.62 & & & & \\
\hline
\end{tabular}

In Table 9 a significant difference is not observed in terms of access to digital sites by the Turkmeni and Turkish school directors $(p=.751, p>.05)$. The score $(\bar{X}=11.08)$ indicates that the average Turkish school directors' score in the sub-dimensions of digital access is higher than school directors in the other country. Bakir (2016) in a study in Digital Citizenship, in classroom observations, teachers can have access to technological environments through the 
criterion specified by ISTE standards, are able to overcome problems faced, can make use of the necessary tools to have access to digital environments and exhibit their skills.

Table 10. A Comparative T-Test Analysis of the Levels of Digital Ethics

\begin{tabular}{lllcccccc}
\hline & Countries & $\mathbf{N}$ & $\overline{\mathbf{X}}$ & SS & t & df & p & Explanation \\
\hline & Turkmenistan & 38 & 14.42 & 2.87 & & & & \\
\hline Digital ethics & & & & & 1.170 & 81 & .072 & $\mathrm{p}>.05$ \\
\hline & TRNC & 45 & 15.64 & 3.23 & & & & \\
\hline
\end{tabular}

A significant difference in ethical levels in digital environments among Turkmenistan and Turkish school directors is not observed ( $\mathrm{p}=.072, \mathrm{p}>.05)$. Bakir (2016) investigated, in a study titled "Digital Citizenship", candidate teachers' behaviors in sub-dimensions of digital ethics and observed no any big differences in the paricipants' scores.

Table 11. A Comparative T-Test Analysis of the Levels of Digital Health

\begin{tabular}{ccccccccc}
\hline \multirow{2}{*}{ Countries } & N & $\overline{\mathbf{X}}$ & SS & $\mathbf{t}$ & $\mathbf{d f}$ & $\mathbf{p}$ & Explanation \\
& Turkmenistan & 38 & 10.71 & 1.57 \\
\hline Digital health & & & & & 8.853 & 81 & .787 & $\mathrm{p}>.05$ \\
\hline \multicolumn{2}{c}{ TRNC } & 45 & 10.84 & 2.83 & & & & \\
\hline
\end{tabular}

Table 11 does not show a significant difference in the levels of health in digital environments between Turkmeni and Turhish school directors ( $=.787, p>.05)$.

Table 12. A comparative analysis of the levels of using mobile-digital equipment

\begin{tabular}{|c|c|c|c|c|c|c|c|c|}
\hline & Countries & $\mathbf{N}$ & $\overline{\mathbf{X}}$ & SS & $\mathbf{t}$ & df & $\mathbf{p}$ & Explanation \\
\hline & Turkmenistan & 38 & 15.78 & 2.68 & & & & \\
\hline $\begin{array}{l}\text { Using } \\
\text { mobile- } \\
\text { digital } \\
\text { equipment }\end{array}$ & & & & & 2.242 & 81 & .730 & $\mathrm{p}>.05$ \\
\hline & TRNC & 45 & 16.02 & 3.42 & & & & \\
\hline
\end{tabular}

As it can be observed in Table 12, there is not a meaningful difference in using mobiledigital equipment between Turkmeni and Turkish school directors $(\mathrm{p}=.730, \mathrm{p} .05)$. Kemp (2016) in a study investigating the number of mobile-phone users in the Turkic Republics found out that the big majority of the people used smart-phones. In the same study, it was observed that the number of mobile phone is higher than the total population; \%161 in Kazakistan, \%144 in Kirgizistan, and \%128 in Turkmenistan. This finding indicates that mobile tools, particularly mobile phones are used efectively among the Turkish people in the world. 
Table 13. A Comparative T-Test Analysis of the Levels of Using Digital Storing Areas

\begin{tabular}{llllllllll}
\hline & Countries & N & $\bar{X}$ & SS & t & df & p & Explanation \\
& Turkmenistan & 38 & 11.28 & 5.11 & & & & \\
\hline $\begin{array}{l}\text { Using digital } \\
\text { storing areas }\end{array}$ & & & & & .320 & 81 & .174 & $\mathrm{p}>.05$ \\
\hline & TRNC & 45 & 12.75 & 4.50 & & & & \\
\hline
\end{tabular}

As in Table 13, a significant difference was not observed in the levels of using storing areas between Turkmeni and Turkish school directors ( $\mathrm{p}=.174, \mathrm{p}>.05)$. In a study by Akcil (2015) it was determined that, according to digital storing sub-dimensions, one of digital citizenship subdimensions, there was not a meaningful difference between the supervisors and the directors of the Ministry of National Education, TRNC. However, when the average scores are overviewed, it was noted that the digital storing areas were used to a great extend.

\section{Conclusion and Recommendations}

Conclusion: The aim of this research was to compare the levels of school directors' Digital Citizenship in the light of the views by Turkmeni and Turkish school directors. The results obtained are as follows;

1. When the rate of Digital Citizenship, based on countries, is examined, the level of digital citizenship of the Turkish (TRNC) secondary education school directors is obserevd to be higher than of the Turkmeni secondary education school directors.

2. The sub-dimensions of Digital Citizenship indicate that the Turkmeni school directors have the lowest level in "digital trade" and the Turkish school directors have the lowest level in "digital security". Both the Turkmeni and Turkish school directors have the highest level in "digital rights and responsibilities".

3. As for the "Digital Citizenship" levels, the Turkish school directors have a higher level $(\overline{\mathrm{X}}=143.95)$ than the Turkmeni directors $(\overline{\mathrm{X}}=128.02)$.

4. A menaingful difference was not observed in "digital literacy" levels of both groups of directors.

5. A meaningful difference in "digital rights and responsibilities" was not noted between the two groups of directors.

6. The Turkish school directors had a higher level in the sub-dimensions of "digital communication" compared to Turkmeni school directors. It was also observed that the Turkmeni school directors had a lower level in communicating through digital technologies.

7. The Turkish school directors' level in the sub-dimensions of "digital security" was noted as higher compared to the Turkmeni school directors.

8. The Turkish school directors had a higher level in "digital trade" compared to the Turkmeni school directors.

9. The Turkmeni school directors had a lower level in the sub-dimension of access to digital environments compared to the level of the Tukish school directors.

10. A meaningful difference in ethical levels in digital environments was not observed between the two groups of directors.

11. A meaningful difference was not observed in the levels of "health in digital environments" between the two groups of directors. 
12. A meaningful difference was not noted in using "mobile digital tools" between the two groups of directors.

13. A meaningful difference was not observed in the levels of using "digital storage areas" between the two groups of directors

\section{Recommendations}

Seminars in in-service training sessions can be organized to improve Turkmeni school directors' perception of Digital Citizenship and its benefits in education.

Workshops, seminars, and presentations can be organized to improve outcome in school environments, inform teachers and students in technology, guide them in how to behave in digital environments, and make them aware of the importance of "Digital Citizenship".

The school directors with a low level of "Digital Citizenship" can be provided with opportunities to develop their behavioral levels.

Turkmeni secondary education school directors make less use of the internet, which has a direct impact on" Digital Citizenship", compared to secondary education school directors in TRNC. Therefore, new laws can be made to end limitations in the use of the internet in Turkmenistan.

It is of utmost importance that, in both Turkmenistan and TRNC, school directors in secondary education should develop themselves in the sub-dimensions of "Digital Citizenship" to be more effective in this digital era.

The sub-dimensions of "Digital Citizenship" showed that the Turkmeni school directors had the lowest level in the sub-dimensions of "digital trade" and the Turkish school directors had the lowest level in the sub-dimensions of "digital security". In this respect, the school directors of both countries should specify their deficiencies in the related sub-dimensions and develop themselves.

\section{References}

Akcil, U. (2015). Dijital Çagda Açık Liderlik ve Dijital Vatandaslik Davranislarinin Yonetim Sureclerine Etkisi. Yayinlanmis Doktora Tezi. Yakin Dogu Universitesi, Lefkosa, KKTC

Alberta. (2012). Digital Citizenship Policy Development Guide. Edmonton. Canada: Alberta Education School Technology Branch

Aslan, S. (2016). Ilkogretim sosyal bilgiler ogretmen adaylarinin dijital vatandaslik davranislarinin bazi degiskenler acisindan incelenmesi. (Yuksek Lisans Tezi). F1rat Universitesi. Turkiye

Aydin, A. (2015). Dijital vatandaslik. Turk Kutuphaneciligi, 29(1), 142-146

Bakir, E. (2016). Sinif ogretmeni adaylarinin dijital vatandaslik seviyelerinin dijital vatandaslik alt boyutlarina gore incelenmesi. Yuksek Lisans Tezi. Karadeniz Teknik Universitesi

Buyukozturk, S., Çakmak, E. K., Akgun, O. E., Karadeniz, S., \& Demirel, F. (2017). Bilimsel arastırma yontemleri. 23. Bask1. Ankara: Pegem Yayincilik 
Canturk, G. (2016). Okul yoneticilerinin teknolojik liderlik davranislari ve bilisim teknolojilerinin yonetim sureçlerinde kullanimi arasindaki iliski. Doktora tezi. Akdeniz Universitesi, Antalya

International Society for Technology Education (ISTE), 2000. National Educational Technology Standards for Teachers. Eugene: ISTE Publications

Kemp, S. (2016). We are social. Digital Yearbook. Erisim Adresi: http://www.slideshare.net/wearesocialsg/2016-digital-yearbook. Accessed 06 February 2016

K1lınç, E., ve Dere, İ. (2013). Lise Ogrencilerinin 'ìi Vatandas' Kavrami Hakkindaki Gorusleri. Journal of Social Studies Education Research, 4(2), 103-124

Mossberger, K. (2008). Digital Citizenship: The Internet, Society and Participation. London, England: The MIT Press

Mossberger, K., Tolbert, C., \& S. McNeal, R. (2007). Digital Citizenship: The Internet, Society and Participation. London, England: The MIT Press

Ozen, F. (2011). Ilkogretim Okulu Yonetici ve Ogretmenlerinin Goruslerine Gore Okul Gelistirme Araci Olarak Hesap Verebilirlik. Yayinlanmis Doktora Tezi. Ankara Universitesi

Safran, M. (2008). Sosyal Bilgiler Ogretimi, Ankara: Pegem A Yayincilik

\section{Biodata of the Corresponding Author}

Assoc. Prof. Dr. Umut Akçıl was born in Nicosia 1983. He completed primary and secondary education at Sht. Tuncer School in Nicosia. Automation Systems section to begin university studies at the University of the Mediterranean (Turkey) was recorded. He graduated from BA and MA in Computer Education and Instructional Technology at Near East University. He graduated from Ph.D. Education Managment, Planing, Economy and Control at Near East Univeristy. In 2015, he became an Assistant Professor in the Department of Education Managment, Planing, Economy and Control at Near East Univeristy. He was an Associate Professor in 2018 in Ataturk Faculty of Education. Since February 2018, he serves as a Vice Dean. He is currently head of chair the Pre-School Teaching department. Assoc. Prof. Dr. Umut Akç1 is the member of academic journals and he has international books chapters, academic publications and research projects. Also, he is members of the civil society organizations. Since 2014, he has written and directed many European Union projects for civil society. 


\title{
USE OF COMPUTERS IN SPECIAL EDUCATION: BENEFITS AND OUTCOMES
}

\author{
Basak Baglama $^{1}$, Yucehan Yucesoy ${ }^{2}$, Mukaddes Sakalli Demirok, ${ }^{3, *}$ \\ ${ }^{1}$ Department of Special Education, Atatürk Education Faculty, Near East University, North Cyprus, Mersin 10 \\ Turkey, basak.baglama@ neu.edu.tr \\ ${ }^{2}$ Department of Teaching Arts, Atatürk Education Faculty, Near East University, North Cyprus, Mersin 10 \\ Turkey, yucehan.yucesoy@neu.edu.tr \\ ${ }^{3}$ Department of Special Education, Atatürk Education Faculty, Near East University, North Cyprus, Mersin 10 \\ Turkey,mukaddes.sakalli@neu.edu.tr \\ Correspondence: mukaddes.sakalli@neu.edu.tr ; Tel.: +90 (392) 2236464
}

\begin{abstract}
Use of computers as effective technological tools in special education has become prevalent in the recent years since it enhances teaching concepts and skills and increase permanence and generalization of learned concepts and skills. Identifying the current situation and trends in a specific field provides a comprehensive perspective for researchers and practitioners. This study aims to examine the current situation and trends in the studies on special education and computer through content analysis. Scopus database was examined in the study in order to carry out the content analysis. Articles published in Scopus database were examined based on certain criteria including year of publication, name of the journals, document type, country and subject area. Data were analyzed based on content analysis method. Results are discussed with reference to relevant literature and implications for further research and practices are also provided.
\end{abstract}

Keywords: computer, special education, benefit, content analysis

\section{Introduction}

Today, it is widely known that using technology promotes appropriate facilities for educational practices. In recent years, there is a dramatic increase in the amount of knowledge and this has an important influence in education and technology facilitates easy access to knowledge (Domingo \& Gargante, 2016; Englund, Olofsson \& Price, 2017). Technologies which entered rapidly into the field of education provide solutions for problems in education and enhance capacity and variability. Developments and innovations in technology change the structure of education and therefore structure of education which will make individuals to adapt to the society need to change as well. Modern technologies are considered as the outcomes of differences caused by technological developments and innovations in education. In light of these developments, method and content of education also changes. Accordingly, educational technology involves every kind of system, technic and support which are formed to develop learning and teaching process in every stage of education beginning from early childhood to higher education (Blackwell, Lauricella \& Wartella, 2014; Sezgin, Erdogan \& Erdogan, 2017).

According to Plowman and Stephen (2005), use of technology is regarded as appropriate when it facilitates effective teaching and learning and provides positive developmental outcomes for learners. For instance, interactive reading-writing programs promotes early reading and writing when compared with other traditional methods. Today, teachers prefer 
digital materials rather than printed materials in teaching concepts and skills. The reason for the prevalent use of technology is related with the effective practices. In addition, content of education could be presented with technology in various ways (Wainwright \& Linebarger, 2006). There are main points which should be considered for an effective collaboration between technology and education (Zoch \& Myers, 2017; Saltan, Turkyilmaz, Karacalti \& Bilir, 2018). These main points are as follows:

- Ways of achieving educational goals when there is no technology,

- Whether technology helps teachers to achieve educational goals,

- Use of technology is appropriate for students' ages,

- Use of technology is appropriate for education programs,

- Educational strategies for technology use,

- Integration of technology into education,

- Technology as a mediator for students to take active role in learning process,

- Whether using technology facilitates family involvement.

There are various technological tools used in education. One of the most prevalently used technological tool in education are computers. Accordingly, concept of "computer-supported education" has come to the fore in the recent years. Given the effective use of technological tools in education including technology, these tools are both used in regular and special education settings and environments (Yadav, Gretter, Hambrusch \& Sands, 2016; McKissick, Diegelmann \& Parker, 2017). Many different methods are used in the education of individuals with special needs and use of technology has become prevalent in special education as well. Use of computers and other technological tools are arranged based on the different needs of individuals with special needs. Contributions of using computers in special education and interests and attitudes of students towards computers and other technologies need to be determined. Computers are considered as a kind of teacher / teaching tool in the lives of individuals with special needs (Johnson, 2013).

In addition to the mentioned advantages of using computers in special education, it should be also noted that using computers promotes permanence and generalization. However, in order to achieve this; student characteristics, content and environment need to be purely determined and organized based on the needs of individuals with special needs. According to the literature, there are certain aims of using technology that enhances special education and rehabilitation practices (Adebisi, Liman \& Longpoe, 2015). These aims generally focus on the following objectives:

- Individuals with special needs should gain communication skills and solutions for social environment and communication problems should be found.

- Individuals with special needs should maintain their lives independently in the society and learn basic life skills.

- Individuals with special needs could be able to use their existing body and mind capacities at the maximum level.

- Individuals with special needs should gain occupational skills if appropriate.

When the literature on special education and use of computers is examined, it is seen that use of computer in special education as a field develops rapidly and there are large amount of researches showing the effectiveness of using computers in special education among individuals with intellectual disability, down syndrome, autism spectrum disorder, learning disability and other special education categories (Stultz, 2013; Lorah, Parnell, Whitby \& Hantula, 2015; Dogan \& Akdemir, 2015; Vereenooghe, Gega, Reynolds \& Langdon, 2016; 
Felix, Mena, Ostos \& Maestre, 2017). In this context, large amount research in this field indicates that there are important developments in the field. Therefore, identifying the current situation and trends in the studies related with computers and special education would enlighten the further research and practices. Therefore, this study aims to examine the studies related with computer and special education in Scopus and reveal the current situation and trends.

\section{Method}

\subsection{Research Model}

Content analysis as a qualitative method was used in this study to examine the published documents related with computer and special education in Scopus database which is one of the international academic databases that indexes a wide variety of journal sources. Content analysis is defined as the examination of verbal or written materials objectively and systematically (Karasar, 2005; Stemler, 2015).

\subsection{Data Collection}

Scopus was selected as the database for the study. The published documents were obtained through searching keywords "computer" and "special education" in order to reveal the current situation and trends in this field. The search page appeared after entering these keywords is provided in Figure 1. All documents published in Scopus on this topic were included in the study and a total number of 4523 published documents were searched, identified and obtained based on the search for the study.

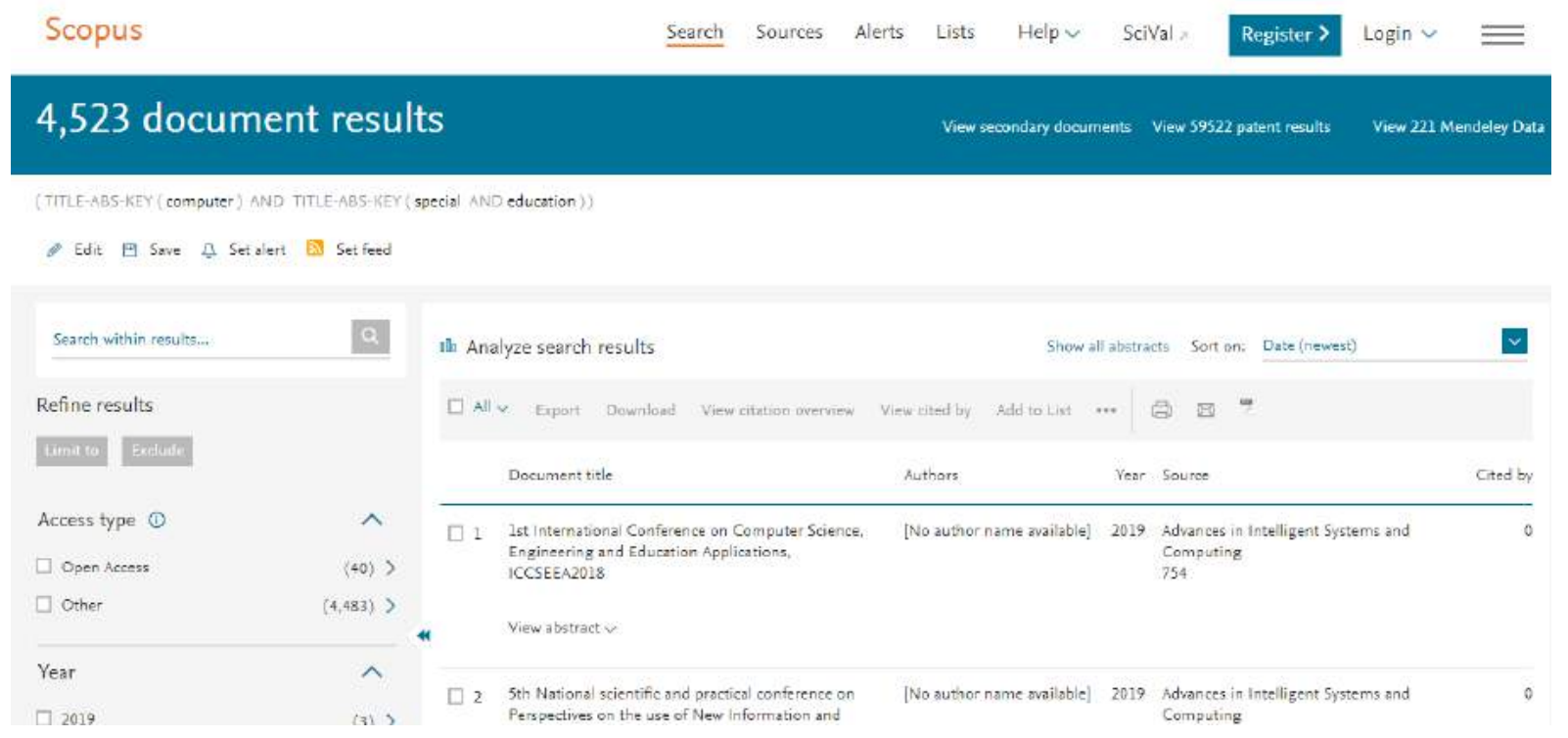

Figure 1. SCOPUS search page for "computer" and "special education"

\subsection{Data Analysis}

Content analysis criteria were determined to examine the published documents in Scopus database for data analysis. These criteria included year of publication, name of the journals, document type, country and subject area. Data were provided with frequency and percentages in tables and figures. 


\section{Results}

\subsection{Distribution of the Published Documents Based On the Year of Publication}

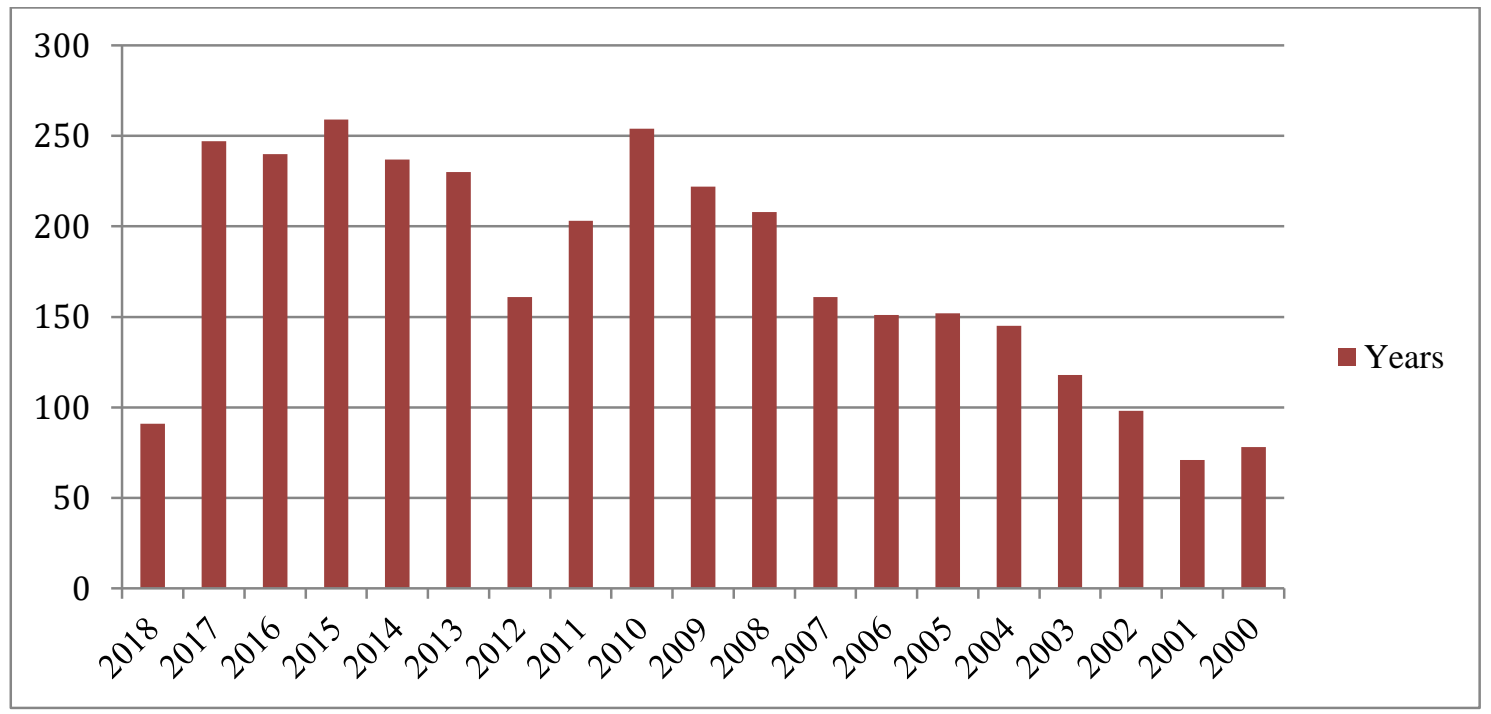

Figure 2. Distribution of the Published Documents Based On the Year of Publication

Figure 2 shows the distribution of the published documents related with computers and special education based on the year of publication in SCOPUS database. The years beginning from 2000 are included in the figure. Results showed that the highest number of publication was in 2015 and 2009. As it can be seen, there is a steady increase in the number of publications on computers and special education throughout the years. The reason of lower number of publication in 2018 is that publications until the end of May 2018 are considered as the data for the study.

\subsection{Distribution of the Published Documents Based On the Name of the Journals}

Table 1. Name of the Journals in Which the Documents Published

\section{Name of journal}

Lecture Notes in Computer Science

American Annals of the Deaf

Communications in Computer and Information Science

Proceedings Frontiers In Education Conference

Journal of Learning Disabilities

Computers and Education

Studies in Health Technology and Informatics

IFIP Advances in Information and Communication Technology

Advances in Intelligent Systems and Computing

ACM International Conference Proceeding Series

\section{f $\quad \%$}

\begin{tabular}{ll}
221 & 4.89 \\
121 & 2.68 \\
63 & 1.39 \\
55 & 1.21 \\
54 & 1.19 \\
43 & 0.95 \\
38 & 0.85 \\
36 & 0.79 \\
35 & 0.77 \\
32 & 0.71 \\
\hline
\end{tabular}

Table 1 shows the name of the journals in which the documents related with computers and special education were published. The first 10 journals with frequent publications are included in the table. According to the results, it is seen that the highest number of publication is in Lecture Notes in Computer Science $(\mathrm{f}=221,4.89 \%)$. This result is followed by American 
Annals of the Deaf $(\mathrm{f}=121,2.68 \%)$ and Communications in Computer and Information Science ( $f=63,1.39 \%$ ). Results showed that there are many different journals which published articles on computers and special education. When the names of the journals are considered, it is also seen that there are different scopes of journals including education, computer science, health technology, informatics, information and communication technology, learning disability and hearing impairment.

\subsection{Distribution of the Published Documents Based On Document Type}

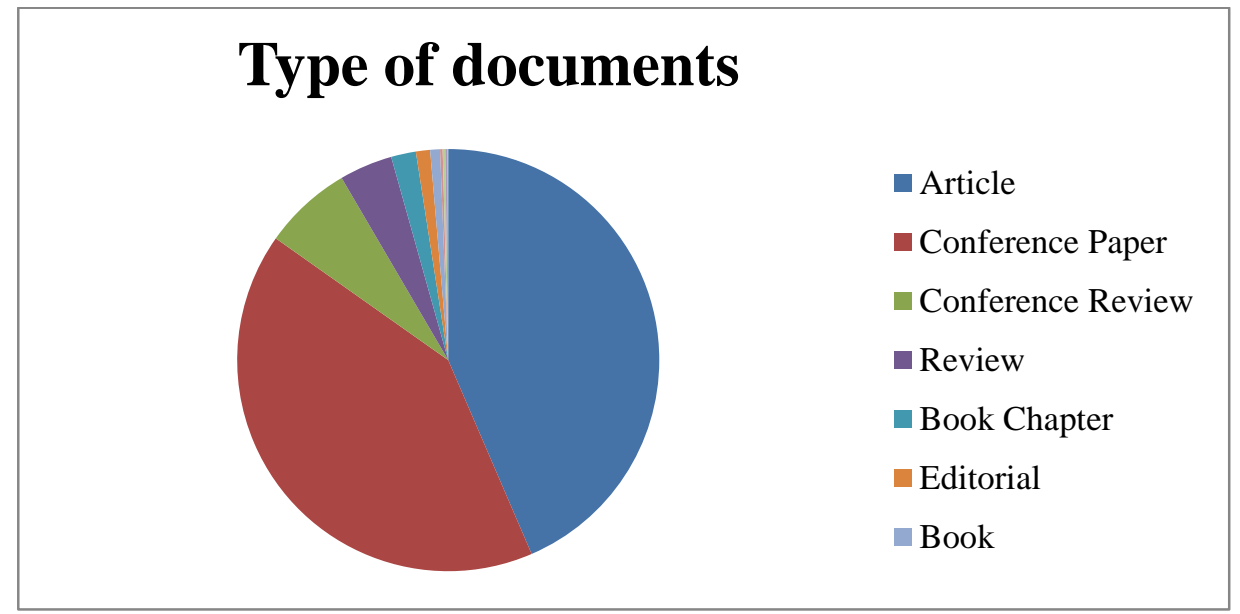

Figure 3. Distribution of the Published Documents Based On Document Type

Distribution of the published documents based on the type of document is provided in Figure 3. As it can be seen from the figure, majority of the published documents were articles and conference papers. Therefore, it can be inferred that authors prefer publishing research articles and conference papers rather than other types of documents. Other types of documents included conference review, book review, review, book chapter, editorial and books.

\subsection{Distribution of the Published Documents Based On the Subject Area}

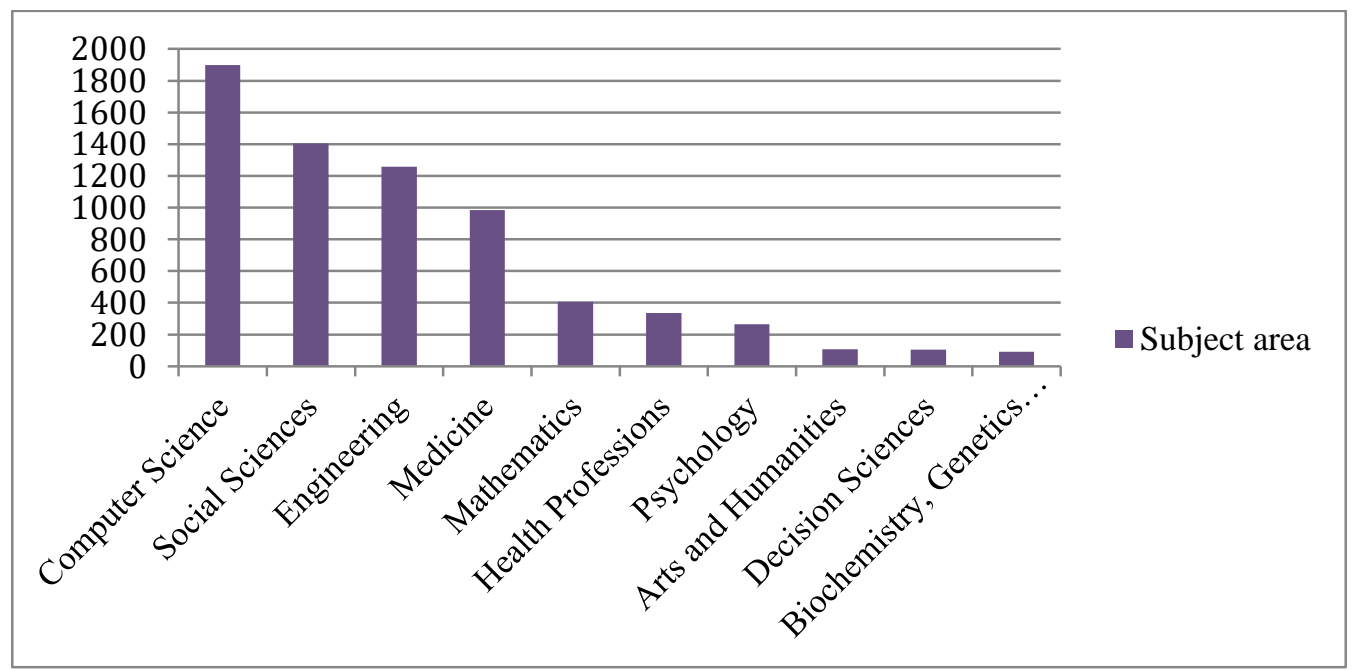

Figure 4. Distribution of the Published Documents Based On Subject Area

Figure 4 shows the distribution of the published documents based on the subject area. The first 10 frequently studied subject area are involved in the figure. Other subject areas were not included in the figure since they have lower frequencies. As it can be seen, computer science was the most frequently studied subject area in the published documents related with computers 
and special education. In addition, social sciences, engineering, medicine, mathematics, health professions, psychology, arts and humanities, decision sciences and genetics were the other frequently studied subject areas from the computer and special education fields. Therefore, it could be inferred that there are various different research topics which studied in the published documents regarding computers and special education.

\subsection{Distribution of the Published Documents Based On Country}

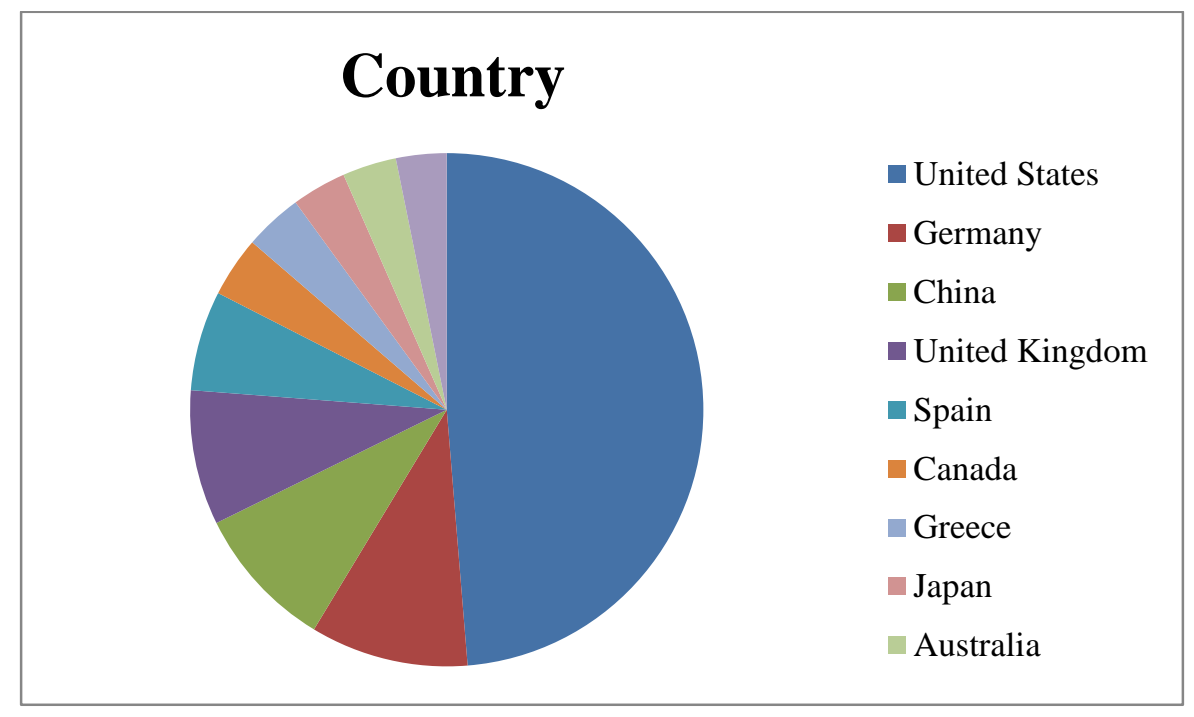

Figure 5. Distribution of the Published Documents Based On Country

Figure 5 demonstrates the distribution of the published documents based on country. The first 10 countries were included in the figure because the other countries were with lower frequencies. According to the results, it is seen that United States is the first country with highest number of publications related with computers and special education in Scopus database. In addition, Germany, China, United Kingdom and Spain were the other countries with high number of publications on computers and special education. These results were followed with Canada, Greece, Japan, Australia and Netherlands.

\section{Discussion}

Computer as a technological tool provides many opportunities for individuals with special needs in terms of many dimensions in order to improve life standards in the society, participate into social life and maintain various skills for learning a profession or living independently in the society. Computers are really important in the education of individuals with special needs. Computer-supported education programs are frequently used in teaching many academic skills such as mathematics, reading-writing, communication skills, other life skills including selfcare skills and daily living skills and basic concepts such as shape, color and opposite concepts. In addition to teaching these skills, computers help individuals with special needs to learn and transfer new knowledge and skills to other situations (Ok, 2018). Given these positive outcomes of computers for individuals with special needs, this study aimed to examine the current situation and trends in the studies on special education and computer through content analysis in order to constitute a systematic review of the scientific research. A total number of 4523 published articles were examined based on previously determined content analysis criteria. 
According to the results obtained from this study, there is a steady increase in the number of publications on computers and special education throughout the years. This is primarily related with the increase in the understanding of effectiveness of computers for individuals with special needs in terms of various dimensions. For instance, Wainer and Ingersoll (2011) emphasized that computers are important tools for teaching social communication to individuals with autism spectrum disorders. Results also showed that there are many different journals which published articles on computers and special education. This might be related with multi-disciplinary nature of the fields of special education and computer research.

Furthermore, results revealed that authors prefer publishing research articles and conference papers rather than other types of documents. As it can be seen, computer science was the most frequently studied subject area in the published documents related with computers and special education. In addition, social sciences, engineering, medicine, mathematics, health professions, psychology, arts and humanities, decision sciences and genetics were the other frequently studied subject areas from the computer and special education fields. Therefore, it could be inferred that there are various different research topics which studied in the published documents regarding computers and special education. Lastly, results showed that United States is the first country with highest number of publications related with computers and special education in Scopus database. Similar with this result, Demirok, Baglama and Besgul (2015) carried out a content analysis study on special education and found that most articles have been published by the authors from United States.

\section{Conclusion and Recommendations}

In this study, current situation and recent research trends in the published studies on computers and special education in Scopus database were determined. In the light of the results obtained from the study, the following recommendations are provided for further research and practices:

- Different databases might be examined for content analysis in order to reveal the current situation and trends in special education and computer research from a more comprehensive perspective.

- Similar studies should be repeated periodically in the future to compare past and current trends.

- In this study, special education as a general category has been investigated. Future studies might examine specific diagnosis and effectiveness of computer applications.

- Special education professionals might receive more training about how to integrate computers into special education practices and be more competent.

\section{References}

Adebisi, R. O., Liman, N. A., \& Longpoe, P. K. (2015). Using assistive technology in teaching children with learning disabilities in the 21 st century. Journal of Education and Practice, 6(24), 14-20

Demirok, M. S., Baglama, B., \& Besgul, M. (2015). A content analysis of the studies in special education area. Procedia: Social and Behavioral Sciences, 197, 2459-2467

Dogan, I., \& Akdemir, O. (2015). Ozel egitimde bilgisayar destekli ogretim: uc durum calismasi. Journal of Higher Education \& Science, 5(2), 165-177 
Domingo, M. G., \& Gargante, A. B. (2016). Exploring the use of educational technology in primary education: Teachers' perception of mobile technology learning impacts and applications' use in the classroom. Computers in Human Behavior, 56, 21-28

Englund, C., Olofsson, A. D., \& Price, L. (2017). Teaching with technology in higher education: understanding conceptual change and development in practice. Higher Education Research \& Development, 36(1), 73-87

Felix, V. G., Mena, L. J., Ostos, R., \& Maestre, G. E. (2017). A pilot study of the use of emerging computer technologies to improve the effectiveness of reading and writing therapies in children with Down syndrome. British Journal of Educational Technology, $48(2), 611-624$

Johnson, G. M. (2013). Using tablet computers with elementary school students with special needs: The practices and perceptions of special education teachers and teacher assistants. Canadian Journal of Learning and Technology, 39(4), 1-12

Karasar, N. (2005). Bilimsel arastirma yontemleri. Ankara: Nobel Yayin Dagitim

Lorah, E. R., Parnell, A., Whitby, P. S. \& Hantula, D. (2015). A systematic review of tablet computers and portable media players as speech generating devices for individuals with autism spectrum disorder. Journal of Autism and Developmental Disorders, 45(12), 3792-3804

McKissick, B. R., Diegelmann, K. M., \& Parker, S. (2017). Using technology to address barriers in rural special education for students with autism: A do-it-yourself guide. Rural Special Education Quarterly, 36(3), 155-159

Ok, M. W. (2018). Use of ipads as assistive technology for students with disabilities. TechTrends, 62(1), 95-102

Plowman, L., \& Stephen, C. (2005). Children, play, and computers in pre-school education. British Journal of Educational Technology, 36(2), 145-157

Saltan, F., Turkyilmaz, T., Karacalti, C., \& Bilir, K. (2018). Use of current educational technology in science education: A scoping review. Cukurova University Faculty of Education Journal, 47(1), 308-336

Sezgin, F., Erdogan, O., \& Erdogan, B. H. (2017). Ogretmenlerin teknoloji oz yeterlikleri: Ogretmen ve ogrenci goruslerine yonelik butuncul bir analiz. Egitim Teknolojisi Kuram ve Uygulama, 7(1), 180-199

Stemler, S. E. (2015). Content analysis. Emerging Trends in the Social and Behavioral Sciences: An Interdisciplinary, Searchable, and Linkable Resource, 1, 1-14

Stultz, L. S. (2013). The Effectiveness of computer-assisted instruction for teaching mathematics to students with specific learning disability. Journal of Special Education Apprenticeship, 2(2), 1-13

Vereenooghe, L., Gega, L., Reynolds, S., \& Langdon, P. E. (2016). Using computers to teach people with intellectual disabilities to perform some of the tasks used within cognitive behavioural therapy: A randomised experiment. Behaviour Research and Therapy, 76, $13-23$

Wainer, A. L., \& Ingersoll, B. R. (2011). The use of innovative computer technology for teaching social communication to individuals with autism spectrum disorders. Research in Autism Spectrum Disorders, 5(1), 96-107 
Wainwright, D. K., \& Linebarger, D. L. (2006). Ready to learn: Literature review. UK: Children's Media Center

Yadav, A., Gretter, S., Hambrusch, S., \& Sands, P. (2016). Expanding computer science education in schools: understanding teacher experiences and challenges. Computer Science Education, 26(4), 235-254

Zoch, M., \& Myers, J. (2017). Teachers' engagement with new literacies as support for implementing technology in the english/language arts classroom. Contemporary Issues in Technology and Teacher Education, 17(1), 25-52

\section{Biodata of the Corresponding Author}

Sakalli Demirok, Mukaddes, Associate Professor, Near East University, and head of the department of special education. She is an author, researcher and lecturer whose interest include special education, giftedness, hearing impairments, down syndrome, autism and scientific study of education. 